University of Chicago Law School

Chicago Unbound

Journal Articles

Faculty Scholarship

1977

\title{
The Effect of Peremptory Challenges on Jury and Verdict: An Experiment in a Federal District Court
}

Hans Zeisel

Shari Seldman Diamond

Follow this and additional works at: https://chicagounbound.uchicago.edu/journal_articles

Part of the Law Commons

\section{Recommended Citation}

Hans Zeisel \& Shari Seldman Diamond, "The Effect of Peremptory Challenges on Jury and Verdict: An Experiment in a Federal District Court," 30 Stanford Law Review 491 (1977).

This Article is brought to you for free and open access by the Faculty Scholarship at Chicago Unbound. It has been accepted for inclusion in Journal Articles by an authorized administrator of Chicago Unbound. For more information, please contact unbound@law.uchicago.edu. 


\title{
The Effect of Peremptory Challenges on Jury and Verdict: An Experiment in a Federal District Court*
}

\author{
Hans Zeisel† \\ Shari Seidman Diamond +
}

Trial lawyers tell us that they occasionally win their cases at voir dire $^{1}$ by the shrewd use of their peremptory challenges. ${ }^{2}$ This is the

- This experiment was conducted in the United States District Court for the Northern District of Illinois and was supported by Grant GS-33825 from the National Science Foundation. Additional funds were provided by the Nancy G. and Raymond G. Feldman Fund for studies in criminal justice.

† Dr. Jur., 1927, Dr. Pol. Sc., 1928, University of Vienna. Professor Emeritus of Law and Sociology, Research Associate, Center for Studies in Criminal Justice, University of Chicago; Senior Consultant, American Bar Foundation.

$\ddagger$ B.A., 1968, University of Michigan; Ph.D., 1972, Northwestern University. Assistant Professor of Criminal Justice and Psychology, University of Illinois at Chicago.

1. Voir dire is sometimes translated from the French as "see [them] talk," but in fact means "true talk," the word voir being a corruption of the Latin verus, or "true". See WEBSTER'S THIRD NEW INT'L DICTIONARY 2562 (1961).

The earliest known procedure for challenging jurors was found in Roman law. The Lex Sevilia (104 B.C.) provided that the accuser and the accused in capital cases could each propose a list of 100 judices and that each could reject 50 from the other's list, leaving 100 to try the case. W. FORSYTH, HISTORY OF TRIAL BY JURY 175 (Cambridge 1852). In the year 7 B.C., the Roman emperor Augustus Caesar issued an edict governing the selection of jurors in capital cases in the city of Cyrene on the Lybian coast (the modern Shahhat). II RoMAN Civilization 37 (N. Lewis \& M. Reinhold eds. 1963). The edict provided for the drawing of 50 prospective jurors, one-half of whom had to be Greek, the other half Roman. The edict added: "Of these the prosecutor may, if he wishes, dismiss one from each group, and the accused three out of the total, provided he does not dismiss either all Romans or all Greeks." Id.

The modern system of challenges for cause and peremptory challenges originated in the common law of England, which allowed peremptory challenges only in criminal trials for capital offenses; the defendant in such an action could exclude 35 jurors. W. ForsYrh, supra at 231. King Henry VIII later reduced this number to 20, where it remained until the mid19 th century. $I d$.

The challenge for cause, allowed by the common law in all cases, was more complex than the present-day system. In Lord Coke's time, the challenge for cause included both the challenge to the array, which led to the exclusion of the entire jury, and the challenge to the polls, which led to the exclusion of individual jurors. Id. at 177. Two classes of cause were recognized: The "principal" challenge was allowed as a matter of course upon a showing that 
report of an experiment designed to discover whether they really do. Normally, this question cannot be answered with precision: Because the excused jurors do not attend the trial, there is no way of knowing how they would have voted had they not been removed. Our experiment attempted to secure this missing information by asking the peremptorily excused jurors to remain as shadow jurors in the courtroom and to reveal at the end of the trial how they would have voted in the case. This allowed us to become retrospectively clairvoyant-to see how well the prosecutor and defense counsel performed in their attempts to eliminate hostile jurors. More important, by combining this knowledge with posttrial interviews of the real jurors, we reconstructed the vote of the jury that would have decided the case had there been no peremptory challengesthat is, if the first 12 jurors in the venire, not excused for cause, had formed the jury. By comparing what the reconstructed "jury without peremptory challenges" would have done with what the real jury did, we were able to gauge the effect, if any, of the peremptory challenges on the composition of the jury and its verdict.

Part I of the Article describes and analyzes the experiment. In Part II, we consider the experiment's significance in the larger framework of the theory and practice of jury selection.

\section{THE EXPERIMENT}

\section{A. The Sample of Cases}

The experiment was conducted in 12 criminal trials before three judges of the United States District Court for the Northern District of Illinois. ${ }^{3}$ Financial considerations limited the number and size of the cases, and we selected only trials that were expected to last no longer than 2 weeks. ${ }^{4}$ Within these bounds, the willingness of the

the sheriff, who chose the jury, was related to one of the parties by blood or affinity. A second objection, the challenge "to the favour," was grounded on an allegation of bias and was decided by two court-appointed officers, called "triors." Id. at 178-79. By the mid-19th century in England, almost all challenges for cause were decided by the triors. Id. at 180 .

2. See, e.g., H. Bodin, Selecting a JURy 8 (1966); I. Goldstein, Trial TechniQue 152 (1935); H. Rothblatt, Successful Techniques in the Trial of Criminal Cases (1951); $R$. Turney, Courtroom Psychology 37 (1924). See generally A. AMSTERdam, B. Segal \& M. Miller, Trial Manual for the Defense of Criminal Cases $\$ 326$ (3d ed. 1974).

3. We would like to thank Judges Hubert L. Will, Philip W. Tone and Frank J. McGarr, and their clerks and marshals, as well as the Clerk of the Court, Stuart Cunningham, and his staff for their assistance and cooperation in this experiment. We also would like to thank Judge Edwin A. Robson, the then-presiding Justice of the Court, for originally authorizing this experiment.

4. Actually, two of the cases in our study lasted somewhat longer than 2 weeks. 
judge, prosecutor and defense attorney to cooperate in the experiment dictated the actual selection of cases. We initially planned to look at both criminal and civil cases, but while the parties to the criminal trials generally gave their consent to the experiment, ${ }^{5}$ we managed to obtain consent in only three civil cases, too small a sample to integrate into our experimental design. In retrospect, the overwhelming refusal rate in civil cases was a blessing, for it gave us a more homogeneous sample of exclusively criminal cases.

Because of these constraints on their selection, the 12 cases that formed the basis of our study are not a probability sample of anything: They are 12 modestly sized criminal jury cases. Therefore, our experiment should be regarded as only the first step toward an understanding of the effect of peremptory challenges on jury verdicts.

The 12 cases included in our experiment spread across the broad range of modern federal criminal litigation. A brief synopsis of each case follows:

Case 1. The defendant was charged with draft evasion. The judge, persuaded by a lost-mail defense, dropped an added count involving failure to respond to induction notices.

Case 2. The defendant, an accountant accused of doctoring his firm's books, had in his possession $\$ 300,000$ that supposedly had been removed from the firm for the refund of a downpayment made by another party for purchase of the firm. The formal counts of the indictment were conspiracy and concealing and controlling transferred property in a bankruptcy case. The defense submitted three documents as its case; it called no witnesses.

Case 3. Two defendants were accused of extortion and conspiracy to commit extortion. The prosecution witnesses were the defendant's co-conspirators and the alleged victim. The purported victim, whose business was taking money from individuals in return for fraudulent promises to secure loans for them, was himself under indictment at the time of trial and subsequently was convicted.

Case 4. The defendant, a young man with no previous record, was accused of knowingly purchasing a stolen television set at a bar where he worked. An FBI agent testified that the defendant admit-

5. Then-United States Attorney James Thompson, now Governor of Illinois, gave general consent to the experiment. As a rule, the defense lawyers gave theirs. In three of the criminal cases we had wanted to examine, however, we could not obtain consent from both sides. Two of these cases involved extortion charges against policemen, and the prosecutors refused to participate in our experiment despite the prior general consent of the United States Attorney. In the other case, the defense was unwilling to cooperate. 
ted knowing that the set was stolen; the defense presented no evidence.

Case 5. The defendant was accused of conspiracy, possession and possession with intent to distribute drugs. The conspiracy charge involved several drugs, including cocaine; the other two counts involved hashish only. The jury did not learn that the alleged ringleader, with whom the defendant lived, already had pleaded guilty. The undercover agent who tried to buy the drugs presented the main testimony; while on the stand, the defendant virtually admitted his involvement in the conspiracy.

Case 6. The defendant was a security guard accused of participating in a scheme to defraud a mail-order house. A roommate and a neighbor of the defendant testified that the defendant received some of the merchandise; a friend of the defendant, however, pleaded guilty and testified that the defendant knew nothing of the fraudulent shipments.

Case 7. The defendant was charged with filing loan applications that contained false information and with selling fake installment contracts to banks. The defense was minimal, and the defendant did not testify.

Case 8. The defendant, a paraplegic, was accused of possession of one stolen automobile and sale of another. He previously had served a prison sentence on a similar charge. The prosecutor produced as witnesses the automobile owners, the person who gave the defendant the automobile referred to in the first indictment, the person who purchased the second automobile, and a person who said he helped to drive the automobiles from where they were stolen. The defendant and his wife, sister and nephew took the stand for the defense.

Case 9. The defendant was accused of possessing seven state checks he knew were stolen and of knowingly passing a forged Treasury check. The defendant purported to make a living by cashing checks for others for a fee, and he claimed that because he had dealt for several years with the people who had given him the checks, he had no reason to believe that the checks were bad.

Case 10. The defendants, a husband and wife accused of several counts of preparation of false income tax forms, allegedly filled out fraudulent forms for people in the community for a $\$ 10$ fee. Only one of the taxpayers spoke English, and an interpreter was present during the trial. The prosecution's case rested on the testimony of these witnesses and on the obvious uniformity of the deductions claimed on the forms.

Case 11. The defendant was a postal employee charged with detaining or delaying the mail. He allegedly placed one sack of mail inside another and put them in an unusual place. The sack was a 
"test" bag with a lock, which indicated that it contained money. Postal inspectors watched the defendant from a roof, but did not wait for him to retrieve the sack. Because it was not retrieved, there was no direct evidence of personal gain. The testimony of the inspectors formed the government's case.

Case 12. The defendant was a politician accused of 12 counts of extortion and five counts of income tax evasion. The prosecutor alleged that the defendant took money in return for favors from his office. The two principal prosecution witnesses-the people who claimed they paid the defendant-were given immunity in exchange for their testimony.

\section{B. Experimental Design}

\section{Voir dire procedure.}

The voir dire procedure in these 12 cases reflected modern federal criminal practice. ${ }^{6}$ In each of the cases, the voir dire was conducted in three phases. In the first phase, the judge informed the entire jury panel of the nature of the case and introduced the

6. For a general discussion of the practice of voir dire in federal cases, see E. DEvITT \& $C$.

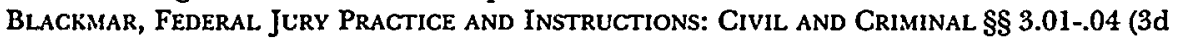
ed. 1977). The manner in which the voir dire is conducted in federal criminal trials is within the trial judge's discretion; the examination of potential jurors may be conducted either by the judge or, with the judge's permission, by the attorneys. FED. R. CRIM. P. 24(a). In practice, most federal judges examine the venire themselves, but allow counsel to submit supplementary questions. C. Wright, Federal Practice and Procedure: Criminal $§ 381$ (1969). The Judicial Conference Committee has recommended that voir dire questioning be conducted exclusively by the trial judge, on the ground that this procedure will save time and improve the character of the examination. The Jury System in the Federal Courts, 26 F.R.D. 409, 424 (1960) (report of the Judicial Conference Committee on the Operation of the Jury System).

Although considerable deference is given to the trial judge's determination of the proper manner of conducting voir dire, an abuse of discretion, such as undue restriction of the scope of voir dire or the inclusion of prejudicial questions, may constitute reversible error. See, e.g., Witherspoon v. Illinois, 391 U.S. 510 (1968); Socony Mobil Oil Co. v. Taylor, 388 F.2d 586 (5th Cir. 1968); Cook v. United States, 379 F.2d 966 (5th Cir. 1967); Progner v. Eagle, 377 F.2d 461 (4th Cir. 1967). See generally Babcock, Voir Dire: Preserving "Its Wonderful Power", 27 STAN. L. REv. 545 (1975).

An attorney has available several methods of challenging jurors. The entire array may be challenged because of the manner in which the venire was drawn, summoned, selected, or impaneled. E. DEvITT \& C. BLACKMAR, supra \$ 3.02. An individual juror may be challenged "for cause" and will be dismissed if the challenging party can show evidence of bias or incompetence. See text accompanying note 7 infra.

Peremptory challenges, unlike those for cause, may be made for any reason, or for no reason. Swain v. Alabama, 380 U.S. 202, 220 (1965). The Supreme Court has stated that such challenges are a "necessary part of trial by jury," $i d$. at 219 , and "one of the most important of the rights secured to the accused," Pointer v. United States, 151 U.S. 396, 408 (1894).

The mechanics of voir dire vary between districts. In some, the jurors are challenged directly by counsel; in others, jurors' names are stricken from a list. Many districts use the method employed by the courts of the state in which the district is located. See E. DEviTT \& C. BLACKMAR, supra $\$ 3.03$. 
attorneys. The judge then asked the prospective jurors several questions designed to elicit their reactions to the alleged offense in the case. In 4 of the 12 cases, certain jurors' answers to these questions resulted in their being excused for cause from the entire venire. ${ }^{7}$

In the second phase, 12 individuals from the venire were placed in the jury box, and the judge asked them in turn to state their names, addresses, occupations, and the occupations of persons living with them. In most of the cases, the judge also asked the prospective jurors to state their length of residence at their present address, their employment for the previous 5 years, the ages of their children, and all instances of prior jury service. In addition, several judges inquired whether the prospective jurors had a close friend or relative who either was involved in law enforcement or had been the victim of a crime. The judge also posed several questions designed to disclose any close associations between the potential jurors and key elements of the case. For example, the judge in Case 5 attempted to discover.whether any of the jurors' friends or relatives ever had used illicit drugs. If a juror had some association with the case, the judge asked whether that association would preclude the juror from making a fair and impartial evaluation of the evidence and merits of the case. Any juror who responded in the affirmative was excused, sent back to the jury room and replaced by a new juror, who was then subjected to the second-phase questioning. All jurors who responded that they had no association with the case, or an association that would not preclude them from fairly and impartially evaluating the case, proceeded to the third phase of voir dire.

In phase three, the prosecutor and defense counsel exercised peremptory challenges. ${ }^{8}$ First, the prosecution exercised as many of

7. A total of 36 jurors were excused for cause in this phase of the voir dire. Fourteen jurors were excused after the second phase, during which they were questioned individually while seated in the jury box.

8. Rule 24(b) of the Federal Rules of Criminal Procedure governs the number of peremptory challenges in federal criminal cases: "If the offense charged is punishable by death, each side is entitled to 20 peremptory challenges. If the offense charged is punishable by imprisonment for more than one year, the government is entitled to 6 peremptory challenges and the defendant or defendants jointly to 10 peremptory challenges. If the offense charged is punishable by imprisonment for not more than one year or by fine or both, each side is entitled to 3 peremptory challenges. If there is more than one defendant, the court may allow the defendants additional peremptory challenges and permit them to be exercised separately or jointly." FED. R. CRIM. P. 24(b).

State laws vary widely concerning the number of peremptory challenges allowed to either side. Generally, both sides have the same number of challenges, but 20 states allow more challenges to the defense under certain circumstances: Delaware, Maine, New Hampshire, New Jersey (capital trials only); Michigan (when the sentence may be either death or life 
its allocated number of peremptory challenges as it desired; the defense was then given the same opportunity. The judge replaced the excused jurors, and the process was repeated with respect to the

imprisonment); Alaska, Arkansas, Kentucky, Maryland, Missouri, Nebraska, South Carolina, Tennessee (all but misdemeanor trials); Alabama, Georgia, Minnesota, New Mexico, North Carolina, Oregon, West Virginia (all trials). The following synopsis summarizes the pattern of allocations of peremptory challenges for 12-member juries in the state courts:

\begin{tabular}{|l|c|c|c|c|c|c|}
\cline { 2 - 7 } \multicolumn{1}{c|}{} & \multicolumn{2}{c|}{ Capital } & \multicolumn{2}{c|}{ Other Felonies } & \multicolumn{2}{c|}{ Misdemeanors } \\
\cline { 2 - 7 } & State & Defendant & State & Defendant & State & Defendant \\
\hline Highest & $\begin{array}{c}26 \\
\text { (Cal.) }\end{array}$ & $\begin{array}{c}26 \\
\text { (Cal.) }\end{array}$ & $\begin{array}{c}15 \\
\text { (N.Y.) }\end{array}$ & $\begin{array}{c}15 \\
\text { (N.Y.) }\end{array}$ & $\begin{array}{c}13 \\
\text { (Cal.) }\end{array}$ & $\begin{array}{c}13 \\
\text { (Cal.) }\end{array}$ \\
\hline Lode & $\begin{array}{c}10 \\
\text { (11 states) }\end{array}$ & $\begin{array}{c}12 \\
\text { (11 states) }\end{array}$ & $\begin{array}{c}6 \\
(14 \text { states) }\end{array}$ & $\begin{array}{c}6 \\
\text { (12 states) }\end{array}$ & $\begin{array}{c}3 \\
\text { (18 states) }\end{array}$ & $\begin{array}{c}3 \\
\text { (15 states) }\end{array}$ \\
\hline $\begin{array}{c}\text { Lowest } \\
\text { (Va.) }\end{array}$ & $\begin{array}{c}4 \\
\text { (Mont., } \\
\text { Va.) }\end{array}$ & $\begin{array}{c}2 \\
\text { (W. Va.) }\end{array}$ & $\begin{array}{c}3 \\
\text { (Hawaii, } \\
\text { N.H.) }\end{array}$ & $\begin{array}{c}2 \\
\text { (Ariz., } \\
\text { Iowa) }\end{array}$ & $\begin{array}{c}2 \\
\text { (Ariz., } \\
\text { Iowa) }\end{array}$ \\
\hline
\end{tabular}

Source: J. Van Dyke, JuRy Selection Procedures 282-83 (1977).

In April 1976, the Supreme Court proposed a number of amendments to the Federal Rules of Criminal Procedure, which, among other things, would have reduced the number of peremptory challenges available to both sides in all criminal cases and would have equalized the number of peremptory challenges available to the prosecution and defense in noncapital felony cases. 44 U.S.L.W. 4549 (1976). The amendments were scheduled to take effect on August 1, 1976, but Congress delayed the effective date until August 1, 1977. Pub. L. No. 94$349, \S 1,90$ Stat. 822 (1976). On July 30, 1977, Congress passed legislation adopting many of the proposed amendments, but specifically rejected the amendment relating to peremptory challenges. Pub. L. No. 95-78, § 2(c), 91 Stat. 319 (1977).

Three arguments were made in favor of the peremptory challenge proposal put forth by the Supreme Court. First, the enactment of the Jury Selection and Service Act of 1968 has led to more representative panels, which have reduced the number of challenges exercised during voir dire and have eliminated the need for the defense to have more challenges than the prosecution. Second, the proposal would make it more difficult for either side systematically to exclude a class of persons from the jury. Third, the proposal would save time and juror costs. S. REP. No. 354, 95th Cong., lst Sess. 9, reprinted in [1977] U.S. CODE CONG. \& AD. NEWS $1477,1482-83$.

The congressional rejection was accompanied by a recommendation that the suggestions be studied further by the Judicial Conference of the United States, the body that, pursuant to 28 U.S.C. $\$ 331$ (1970), considers proposed rule changes and forwards them to the Supreme Court. S. REP. No. 354, 95th Cong., 1st Sess. 9, reprinted in [1977] U.S. CoDE CONG. \& AD. News at 1483. The Senate Judiciary Committee noted that the amendments relating to peremptory challenges had stirred more controversy than any of the other proposed rule changes. Id., [1977] U.S. CoDE CONG. \& AD. NEws at 1482. The Committee stated that most of the opposition arose from a fear that the proposal was ill-conceived in view of the widespread practice of allowing judges, not counsel, to conduct voir dire: "Witnesses indicated that [not permitting attorneys to question venire members] makes it difficult for counsel to identify biased jurors and develop grounds to challenge for cause." Id., [1977] U.S. CODE CONG. \& AD. News at 1483. The Committee concluded that "the Judicial Conference should have the benefit of the comments that have been made on this rule since it was submitted to Congress in deciding whether to make such a change in the future." Id. 
newly impaneled venire members. Any prospective juror accepted without challenge by both attorneys became a member of the jury and was no longer subject to challenge. The jury finally was filled when the 12th member of the venire successfully completed phase three without being excused.

The experiment introduced one modification into the voir dire procedure in order to avoid the possibility that a peremptorily challenged juror would resent-and therefore vote against-the side that exercised the challenge. In ordinary practice, an attorney wishing to exercise a challenge announces the juror's name in open court. In the experiment, the attorneys simultaneously submitted special challenge sheets to the judge. After reviewing both sheets, the judge announced the names of the challenged jurors without revealing the source of dismissal.

\section{Formation of the experimental juries.}

After the real jury was impaneled and sent to the jury room, the court asked the peremptorily excused jurors and the remaining venire members to participate in the study. The judge emphasized the importance of the study and explained to the jurors that they would be paid for their participation as part of their regular jury service. Almost $90 \%$ of those invited agreed to serve in our experiment.

In each case, the judge asked the peremptorily challenged jurors to form a shadow jury and seated them in the first row of spectator seats. The size of these shadow juries varied from case to case depending on the number of peremptorily excused jurors and their willingness to cooperate with the experiment. Although our study required only the pre-deliberation votes of the peremptorily excused jurors, we formed them into "juries" to ensure that they would take their task seriously. ${ }^{9}$

The court then formed a second shadow jury by random selection from the remainder of the venire. This jury was seated without the benefit of voir dire-that is, without questioning and challenges-and therefore was dubbed the "English jury," because challenges, although permitted in England, are almost never exer-

9. See note 13 infra and accompanying text. 
cised. ${ }^{10}$ Only four of the "English juries" had a full complement of 12 members. One jury (Case 11 ) required only 6 members to match the real jury; ${ }^{11}$ in another case (Case 12 ), we were unable to recruit a jury at all; the remaining six juries varied in size between 7 and 10 members.

Thus, each case actually was tried to three "juries": the real jury, another composed of peremptorily challenged jurors, and still a third containing jurors randomly selected from the remainder of the venire. Table 1 presents the number of persons in each of these juries for our sample of 12 cases.

\section{TABLE 1}

Number of Persons in Each Experimental Jury

\begin{tabular}{|c|c|c|c|}
\hline Case No. & Real Jury & $\begin{array}{c}\text { Peremptorily } \\
\text { Excused Jury }\end{array}$ & "English Jury" \\
\hline 1 & 12 & 12 & 12 \\
2 & 12 & 5 & 12 \\
3 & 12 & 9 & 10 \\
4 & 12 & 4 & 10 \\
5 & 12 & 6 & 7 \\
6 & 12 & 7 & 9 \\
7 & 12 & 4 & 12 \\
8 & 12 & 9 & 9 \\
9 & 12 & 8 & 12 \\
10 & 12 & 8 & 6 \\
11 & 6 & 5 & - \\
12 & 12 & 8 & 109 \\
\hline Total & 138 & 85 & 6 \\
\hline
\end{tabular}

Throughout the trial and even during meal times and recesses, all three juries were treated as much alike as possible. Both shadow

10. "The English tradition is that advocacy should be quite impersonal: . . . [counsel] should address the jury as an impersonal body of twelve and the less they know about them as men and women the better." P. DEvLIN, TRIAL BY JURY 34 (1956). But Devlin himself recalls a trial in which after the verdict was rendered, it was discovered that two of the jurors could not speak English. Id. at 35. I (H.Z.) once asked the late Chief Justice, Lord Parker of Waddington, "What if one of the jurors were a cousin of the defendant?" With just the hint of a smile, he answered, "Wouldn't that be awkward?"

11. Case 11 was tried to a jury of 6, pursuant to FED. R. CRIM. P. 23(b), under which a case may be tried by a jury of less than 12 upon written stipulation of the parties and approval of the court. 
juries were seated in the front row of the spectator section. When the real jury was removed from the courtroom to keep it from hearing certain testimony, the experimental juries were removed, too; when exhibits were passed out to the real jurors during the trial, the experimental jurors saw them at the first recess. At the end of the trial, the three juries retired to their separate jury rooms to deliberate and reach a verdict. And if the real jury took documents into its deliberation room, the shadow juries received copies, even in the case in which there were some 200 pages of bookkeeping forms.

Before the two shadow juries began their deliberations, we passed each juror a secret predeliberation ballot. ${ }^{12}$ During the deliberations, which were tape-recorded, the shadow juries were treated like the real jury. If one of the experimental juries asked a question during deliberations, the judge received it and responded as he would have to a real jury. In one case, this even involved calling a shadow jury back into the courtroom and reinstructing it.

As was to be expected, the shadow jurors took their task seriously. Earlier experiments have indicated that mock juries, even when confronting simulated, tape-recorded cases, become involved quickly and deeply in their tasks. ${ }^{13}$ In our experiment, both the substance and length of the deliberations of the shadow juries supported the expectation of serious involvement. The average deliberation time for the real juries was 2 hours, 38 minutes; for the experimental juries, it was 2 hours, 12 minutes. Moreover, the recorded deliberations of the shadow juries revealed many heated arguments-expletives not deleted-and extensive discussions of the evidence and the questions raised during the trials.

\section{Reconstructing the "juries without challenges."}

Our experimental goal was to reconstruct the juries that would have decided each case had there been no peremptory challenges and to ascertain their verdicts had they been the actual juries. The first part of our task presented no difficulty. The transcribed minutes of the voir dire proceedings provided us with the order in

12. We also distributed a questionnaire to the presiding judge in each case, see note 3 supra, asking him how he would have decided the case had it been a bench trial. This enabled us to measure the extent of judge-jury disagreement on verdicts and its relationship to the exercise of peremptory challenges. For the results of this comparison, see text accompanying notes 27-33 infra.

13. See R. Simon, The Jury and the Defense of Insanity 175-79 (1967). See also S. McCabe \& R. Purves, The Shadow Jury at Work 4-5 (1974). 
which the prospective jurors in each case entered the jury box. To reconstruct the "juries without challenges," 14 we merely had to read off the names of the first 12 , and in one case $6,,^{15}$ jurors entering the jury box who were not excused for cause. ${ }^{16}$ These groups represented the juries that would have rendered verdicts in the cases had no peremptory challenges been made. Table 2 shows the composition of each of our 12 reconstructed juries.

\section{TABLE 2}

\section{Component Parts of the Reconstructed "Juries Without Challenges"}

\begin{tabular}{|c|c|c|c|c|c|}
\hline \multirow[b]{2}{*}{ Case No. } & \multicolumn{3}{|c|}{ Peremptorily Excused } & \multirow[b]{2}{*}{$\begin{array}{l}\text { Real } \\
\text { Jurors }\end{array}$} & \multirow[b]{2}{*}{ Tota } \\
\hline & $\begin{array}{c}\text { Vote } \\
\text { Known }\end{array}$ & $\begin{array}{c}\text { Vote } \\
\text { Estimated* }\end{array}$ & Total & & \\
\hline 1 & 5 & 0 & 5 & $7 * *$ & 12 \\
\hline 2 & 3 & 0 & 3 & 9 & 12 \\
\hline 3 & 5 & 0 & 5 & $7^{* *}$ & 12 \\
\hline 4 & 3 & 0 & 3 & 9 & 12 \\
\hline 5 & 6 & 1 & 7 & 5 & 12 \\
\hline 6 & 3 & 3 & 6 & 6 & 12 \\
\hline 7 & 4 & 0 & 4 & 8 & 12 \\
\hline 8 & 5 & 0 & 5 & 7 & 12 \\
\hline 9 & 4 & 1 & 5 & 7 & 12 \\
\hline 10 & 4 & 1 & 5 & 7 & 12 \\
\hline 11 & 4 & 1 & 5 & 1 & 6 \\
\hline 12 & 4 & 2 & 6 & 6 & 12 \\
\hline
\end{tabular}

- See notes 17-20 infra and accompanying text.

-. First ballot estimated. See note 20 infra.

14. Throughout the remainder of this Article, we shall refer to the reconstructed jury as simply the "jury without challenges," even though it did not include any jurors who had been excused for cause, see note 16 infra, and is therefore technically the "jury without peremplory challenges." In contrast, what we have dubbed the "English jury" may have included a few jurors who would have been excused for cause had they undergone the individual questioning during voir dire. See generally text accompanying notes 34-35 infra.

15. See note 11 supra.

16. A judge may dismiss for cause any juror believed to be biased or unqualified and has broad discretion in ruling on challenges. Dennis v. United States, 339 U.S. 162, 168 (1950); United States v. Johnson, 401 F.2d 746, 747 (2d Cir. 1968); United States v. Palumbo, 401 F.2d 270, 275 (2d Cir.), cert. denied, 394 U.S. 947 (1968). Usually, federal judges liberally dismiss for cause prospective jurors against whom plausible grounds for objection can be stated. See, e.g., United States v. Kline, 221 F. Supp. 776, 780 (D. Minn. 1963). Additionally, the judge may ask the jurors whether they will be influenced by possible prejudicial matters 
Our second objective, to ascertain the reconstructed juries' verdicts, required an intermediate step. Because the members of the reconstructed juries never met together or deliberated as a body, their verdicts could not be established directly. To overcome this difficulty, we adopted a 2-step procedure. First, we estimated what the first ballot vote of the reconstructed "jury without challenges" would have been. Then, using an insight from an earlier study, we used this first ballot vote to predict the likely verdict. ${ }^{17}$

In order to ascertain the first ballot vote of each reconstructed jury, it was necessary to establish the first ballot votes of the members of the two groups constituting the reconstructed jury: (1) the peremptorily excused jurors, and (2) those members of the real jury who also would have been on the "jury without challenges." To determine the first ballot votes of the peremptorily excused jurors, we obtained their individual verdicts after they had observed the trial. The votes of the nine excused jurors who declined to participate in the experiment were estimated by assuming that the attorneys followed a consistent pattern in challenging prospective jurors. ${ }^{18}$ Consequently, we assigned votes to these jurors in the same proportion as the first ballot votes of the other jurors excused by the same counsel in the same trial. ${ }^{19}$

and may give weight to their assurances that they will be fair in evaluating the evidence. See, e.g., Murphy v. Florida, 421 U.S. 794, 800 (1975).

In our experiment, the number of dismissals for cause varied considerably from case to case. In 4 of the 12 trials, the challenges for cause were based upon questions addressed to the entire venire. In one case that involved local politics (Case 12), there were 17 such excuses; in a draft evasion case (Case 1), there were 8; in a drug case (Case 5), 6; and in a misdemeanor case involving the purchase of a stolen T.V. set (Case 4), there were 5. The remaining 8 cases averaged 1.75 challenges for cause: 9 in the case of theft from a mail-order house (Case 6), 3 in the case involving extortion and an alleged use of a gun (Case 3), 1 each in 2 others (Cases 10 and 11), and none in the remaining 4 cases. None of the jurors excused for cause was allowed to serve on either the "jury without challenges" or the "English jury."

17. See H. Kalven \& H. Zeisel, The American Jury 487-91 (1966).

18. This assumption of consistency, though likely to be valid in most situations, does not take into account a factor that may be at work early in the peremptory challenge procedure: Attorneys may decide to accept a somewhat hostile juror rather than risk exhausting all their challenges too quickly and later facing venire members who are even more hostile. This factor, however, should not have affected our assumption in this experiment, because in all the cases except one, the attorneys did not exhaust their allotted peremptory challenges. The one exception was a misdemeanor case (Case 4) in which́ each side was allotted 3 challenges; the defense used all 3.

19. In one case (Case 9), the only juror excused by the prosecutor declined to participate in the study. We therefore assumed a neutral performance by the prosecutor. See notes $45-49$ infra and accompanying text. Because the prosecutor used only this one challenge, the attorney performance index score would be close to zero regardless of how that juror might have voted. See id. 
An assumption was also needed to determine the first ballot vote of those real jurors who were part of the reconstructed jury. In 10 of the cases, we learned the overall first ballot votes of the full juries, but not the votes of individual jurors. Thus, although we knew which jurors would have been on the reconstructed jury, we could not learn how each voted on the first ballot. As a result, we had to assume that those real jurors who would have been on the "jury without challenges" voted in the same guilty/not guilty ratio as did the jury as a whole. For example, if there were 8 real jurors who would have been on the "jury without challenges" and the real jury split on the first ballot was 6 guilty and 6 not guilty votes, we assumed that the 8 jurors on our reconstructed jury divided their votes in the same ratio: 4 guilty and 4 not guilty. ${ }^{20}$

By combining these various approaches, we estimated the first ballot votes of all 12 reconstructed juries. As an example, Table 3 illustrates the computation of the first ballot vote of the reconstructed jury in Case 10 .

20. This procedure assumes that the real jurors on the reconstructed juries were a random sample of the real jurors as a whole. See note 18 supra and accompanying text. In the remaining two cases (Cases 1 and 3), we were not allowed to learn even the constellation of the first ballot votes of the real juries. In order to estimate the votes of these members of the juries who would have been on the "juries without challenges," we relied on previous studies suggesting that, in an uncomplicated case, lengthy jury deliberations occur most often when a significant minority of jurors disagree with the majority vote on the first ballot. See H. KaLVEN \& $\mathrm{H}$. ZEISEL, supra note 17, at 462 ("[J]uries which begin with an overwhelming majority in either direction are not likely to hang. It requires a massive minority of 4 or 5 jurors at the first vote to develop the likelihood of a hung jury."). In both of these cases, the juries deliberated for a considerable length of time before ultimately acquitting the defendant. Therefore, we assumed that a slight majority of the jurors initially believed the defendant innocent, see Table 3 and note 23 infra, and we assigned each jury a first ballot vote of 5 guilty and 7 not guilty.

We considered two other possible explanations for the lengthy deliberations. First, juries generally deliberate longer in cases involving numerous complex issues than in cases involving only a few simple issues. See H. KALVEN \& H. ZeISEL, supra note 17, at 457. Because the issues in the cases used in the experiment were relatively uncomplicated, however, this first explanation was rejected. The second possible explanation is that in these cases a small minority of recalcitrant jurors prevented a unanimous verdict. There has been considerable research, however, indicating that participants in jury deliberations frequently are influenced to change their votes as a result of the knowledge that an overwhelming majority disagree with them. See the authorities collected in Note, On Instructing Deadlocked Juries, 78 Y ALE L. J. 100 (1968). Consequently, we concluded that the long deliberations indicated that the phenomenon of a few holdout jurors was not in effect here. 


\section{TABLE 3}

\section{Reconstructing the First Ballot Vote of the "Jury Without Challenges" in Case 10}

Seven members of the real jury would have been on the

$\frac{\text { First Ballot Vote }}{\text { Guilty Not Guilty }}$
"jury without challenges." The first ballot of the real jury was 11 to 1 (92\% to $8 \%$ ) for conviction. This ratio, applied to the 7 real jurors, yields a vote of

Four excused jurors whose votes we knew from the experiment

One excused juror declined to participate in the experiment. He was dismissed by the prosecutor, who challenged four other jurors. Because their votes were 1 guilty, 3 not guilty, the fifth juror's vote was estimated at

$\frac{.25}{8.65}+\frac{.75}{3.35}=12$
$72 \%+28 \%=100 \%$

\section{Predicting the likely verdict.}

From the estimated first ballot vote of each reconstructed "jury without challenges," we predicted the likely trial verdict in each case. A study reported by Kalven and Zeisel in The American Jury ${ }^{21}$ showed that $92 \%$ of all jury verdicts are decided by the first ballot vote. ${ }^{22}$ Rarely does the minority position become the final verdict; moreover, the greater the degree of agreement on the first ballot, the higher the probability that the majority decision will prevail. ${ }^{23}$

21. H. KALVEN \& H. ZEISEL, supra note 17.

22. Id. at 488. See notes 23-24 infra.

23. H. KALVEN \& H. ZEISEL, supra note 17 , at 489 . Kalven and Zeisel conducted interviews with jurors in Chicago and Brooklyn who had participated in criminal trials. By ascertaining the jurors' first ballot votes, the authors were able to determine the relationship between first ballot votes and the jury verdicts in 225 cases. In $31 \%$ of the cases the first ballot was unanimous ( $12 \%$ not guilty, $19 \%$ guilty). $I d$. at 487 . In the remaining cases, the first ballot foretold the final outcome with extreme accuracy. In $86 \%$ of the cases in which a majority of the jurors initially voted guilty, the trial resulted in conviction. Similarly, of those cases in which only a minority of the jurors favored conviction on the first ballot, $91 \%$ ended in acquittal. In the remaining $4 \%$ of the cases, in which the initial vote was split evenly, exactly one-half resulted in acquittal and one-half in conviction. Id. at 488 . The authors concluded 
By extrapolating from this insight into the relationship between the first ballot and verdict, we were able to estimate for each of our trials the probable verdict of the "jury without challenges."

Graph 1 is a freehand interpolation of the relationship found by Kalven and Zeisel between first ballot votes and the likelihood of a given verdict after deliberation. ${ }^{24}$

\section{GRAPH 1}

Generalized Relationship Between First Ballot Vote and Final Verdict

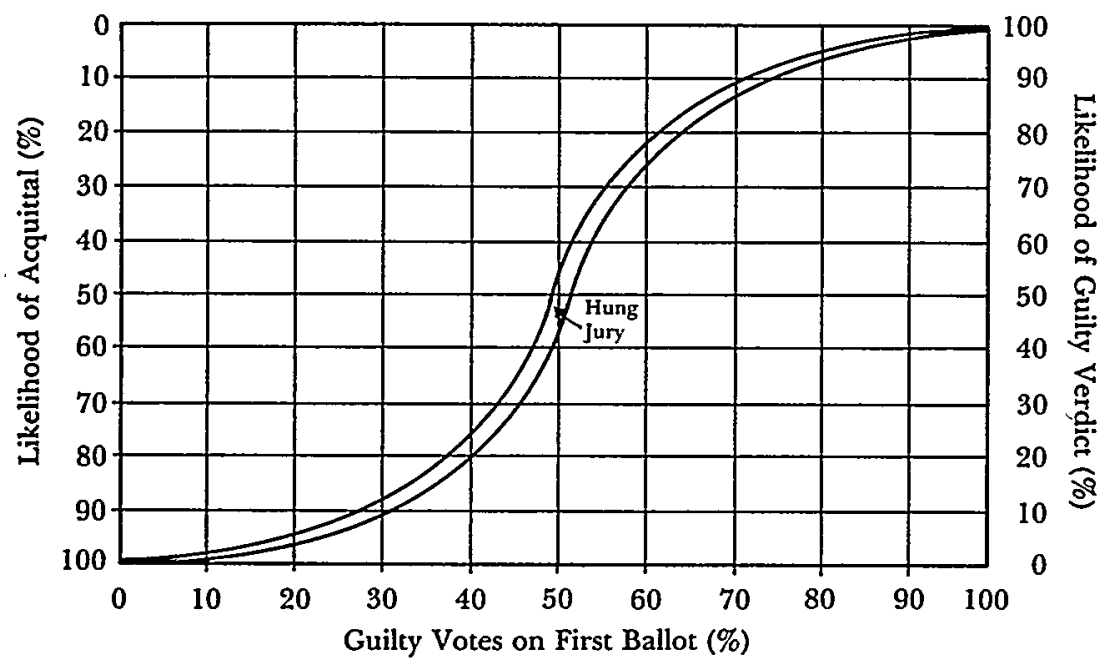

that, with few exceptions, jury verdicts are decided on the first ballot: "The upshot is a radical hunch about the function of the deliberation process. Perhaps it does not so much decide the case as bring about the consensus, the outcome of which has been made highly likely by the distribution of first ballot votes. The deliberation process might well be likened to what the developer does for an exposed film: it brings out the picture, but the outcome is predetermined." Id. at 489.

The importance of the first ballot in determining the eventual verdict has been confirmed repeatedly by other studies. See, e.g., Davis, Kerr, Atkin, Holt, \& Meek, The Decision Processes of 6-and 12-Person Mock Juries Assigned Unanimous and Two-Thirds Majority Rules, 32 J. PERsonALITY AND SOC. PSYCH. 1 (1975).

24. See note 23 supra. The curves in Graph 1 are based on the data in the following table 
The percentage of guilty votes on the first ballot is plotted along the horizontal axis. For any given first ballot percentage, the height of the lower curve (indicated on the rightmost vertical axis) represents the probability that a guilty verdict will be returned; the distance above the upper curve (indicated on the leftmost vertical axis) denotes the likelihood of acquittal; the vertical distance between the two curves represents the probability of a hung jury. For any given first ballot vote, therefore, we can estimate the probabilities of each of the possible trial verdicts.

For example, the first ballot vote of the reconstructed jury in Case 10 was calculated to be $72 \%$ guilty, $28 \%$ not guilty. Finding the $72 \%$ figure on the baseline of Graph 1 and reading vertically, we estimate that the reconstructed jury had an $88 \%$ chance of convicting, a $9 \%$ chance of acquitting and a $3 \%$ chance of reaching no verdict. With these figures, we can compare the estimated verdict of the "jury without challenges" with the verdict of the real jury.

\section{Results of the Experiment}

\section{Impact of challenges on the verdict.}

Table 4 summarizes the results of our experiment. For each case, we have used the relationship pictured in Graph 1 to convert the first ballot votes of the reconstructed and real juries (columns 1 and 2) into the relative likelihood of guilty verdicts (columns 3 and 4). The actual verdict of the real jury is recorded in column 5 . Column 6 , computed by subtracting column 3 from column 4 , represents the shift in the probability of a guilty verdict as a result of the peremptory challenges. A negative score indicates a decrease in the likelihood of a guilty verdict, a positive score indicates an increase, and a score of zero shows that the peremptory challenges did not affect the probability of a guilty verdict.

from $H$. KALVEN \& $H$. ZEISEL, supra note 17 , at 488 :

First Ballot and Final Verdict in 225 Criminal Jury Trials

\begin{tabular}{|c|c|c|c|c|c|c|}
\hline \multirow[b]{2}{*}{ Final Verdict } & \multicolumn{5}{|c|}{ Number of Guilty Votes on First Ballot } & \multirow{2}{*}{$\begin{array}{l}\text { Percent } \\
\text { of Cases }\end{array}$} \\
\hline & 0 & $1-5$ & 6 & $7-11$ & 12 & \\
\hline $\begin{array}{l}\text { Not Guilty } \\
\text { Hung Jury } \\
\text { Guilty }\end{array}$ & $\begin{array}{c}100 \\
- \\
-\end{array}$ & $\begin{array}{r}91 \\
7 \\
2\end{array}$ & $\begin{array}{c}50 \\
- \\
50\end{array}$ & $\begin{array}{r}5 \\
9 \\
86\end{array}$ & $\begin{array}{c}- \\
100\end{array}$ & $\begin{array}{r}32.8 \\
5.5 \\
61.7\end{array}$ \\
\hline Percent of Cases & $12 \%$ & $18 \%$ & $4 \%$ & $47 \%$ & $19 \%$ & $100 \%$ \\
\hline
\end{tabular}


TABLE 4

Comparison of the Reconstructed "Juries Without Challenges" and the Real Juries After Challenges

\begin{tabular}{|c|c|c|c|c|c|c|}
\hline \multirow[b]{2}{*}{$\begin{array}{l}\text { Case } \\
\text { No. }\end{array}$} & \multicolumn{2}{|c|}{$\begin{array}{c}\text { Percentage Guilty Votes } \\
\text { On First Ballot }\end{array}$} & \multicolumn{2}{|c|}{$\begin{array}{c}\text { Corresponding Percentage } \\
\text { Probability That the } \\
\text { Verdict Will Be } \\
\text { Guilty* }\end{array}$} & \multirow[b]{2}{*}{$\begin{array}{l}\text { Actual } \\
\text { Verdict }\end{array}$} & \multirow[b]{2}{*}{$\begin{array}{c}(4)-(3) \\
\text { Percentage Shift } \\
\text { in Probability } \\
\text { of Guilty Verdict } \\
\text { as a Result } \\
\text { of Challenges }\end{array}$} \\
\hline & $\begin{array}{l}\text { "Jury Without } \\
\text { Challenges" }\end{array}$ & $\begin{array}{l}\text { Real } \\
\text { Jury }\end{array}$ & $\begin{array}{l}\text { “Jury Without } \\
\text { Challenges" }\end{array}$ & $\begin{array}{l}\text { Real } \\
\text { Jury }\end{array}$ & & \\
\hline 10 & 49 & 42 & 41 & 23 & NG & -18 \\
\hline 2 & 88 & 83 & 96 & 94 & G & -2 \\
\hline 3".." & 41 & 42 & 22 & 23 & NG & +1 \\
\hline 4 & 50 & 33 & 42 & 11 & NG & -30 \\
\hline 5 & 77 & 83 & 91 & 94 & G & +3 \\
\hline 6 & 53 & 50 & 55 & 42 & NG & -13 \\
\hline 7 & 72 & 83 & 89 & 94 & G & +5 \\
\hline 8 & 100 & 100 & 100 & 100 & G & 0 \\
\hline 9 & 50 & 50 & 42 & 42 & Hung & 0 \\
\hline 10 & 72 & 92 & 89 & 97 & G & +8 \\
\hline 11 & 38 & 17 & 17 & 2 & NG & -15 \\
\hline 12 & 67 & 33 & 84 & 12 & NG & -72 \\
\hline
\end{tabular}

- Percentages are interpolated from Graph 1. See note 23 supra and accompanying text.

- Assuming an initial vote of 5 to 7. See note 20 supra. If an initial vote of 6 to 6 is assumed, (1) becomes $54 \%$ and (2) becomes $50 \%$; if 4 to 8 is assumed, (1) becomes $44 \%$ and (2) becomes $33 \%$.

*.* Assuming an initial vote of 5 to 7 . If an initial vote of 6 to 6 is assumed, (1) becomes $46 \%$ and (2) becomes $50 \%$; if an initial vote of 4 to 8 is assumed, (1) becomes $36 \%$ and (2) becomes $33 \%$.

These data provide a preliminary answer to our question of whether peremptory challenges affect jury verdicts. In 7 of the 12 cases, the combined effect of the challenges was minimal and did not produce the expectation that the verdict of the "jury without challenges" would have differed from that of the real jury. In the remaining cases, the probability of a guilty verdict shifted at least 13 points. ${ }^{25}$ The most striking shift in probability occurred in Case 12.

25. In Cases $1,4,6,11$, and 12 , the shifts were $-18,-30,-13,-15$, and -72 , respectively. 
The real jury in that case voted for acquittal, while the reconstructed jury almost certainly would have convicted the defendant. ${ }^{26}$

Peremptory challenges changed the expected verdict in Case 6 as well. Although a conviction was the probable verdict of the "jury without challenges," the likely-and obtained-verdict of the real jury was acquittal.

The three other large shifts in probability occurred in Cases 1,4 and 11. In Case 11, the shift in guilty votes was from $17 \%$ to $2 \%$, beginning and ending with the strong expectation of an acquittal. In Cases 1 and 4, the effect of the challenges was to shift the probability of conviction from a value close to the $50 \%$ mark, where the expected verdict changes, to a probability substantially below that mark. The probability shifts described here suggest that peremptory challenges had a substantial role in altering the likelihood of guilty verdicts.

\section{Judge-jury disagreement.}

The trial judges' reactions to the verdicts in our sample cases show an intriguing correlation with the findings reported in the previous section. We asked each judge to tell us how he would have decided the case had it been a bench trial. If a judge disagreed with the jury's verdict, he also was asked to disclose the extent of his disagreement by characterizing the jury verdict in one of three ways: (1) a verdict a judge might also reach; (2) a verdict tenable for a jury, though not for a judge; or (3) a verdict without merit. ${ }^{27}$ Table 5 presents the results.

26. Based on the first ballot votes, the "jury without challenges" had an $84 \%$ probability of convicting the defendant. In other words, if the same defendant were tried 100 different times and each time the jury's first ballot votes were the same as those of the reconstructed jury in this case, the defendant would be convicted 84 times. In contrast, the first ballot votes of the real jury indicate that they would have convicted the defendant only 12 times out of 100.

27. Our approach was modeled on a technique developed in The American Jury. See H. KALVEN \& H. ZEISEL, supra note 17 , at $428-33$. The American Jury found that judges agreed with the jury's verdict in over two-thirds of the cases, id. at 429 (Table 112), but that when the judges disagreed with the jury's verdict on the issue of guilt, they considered one-third of these jury verdicts "without merit," id. at 430 (Table 113). The "without merit" criticism captured such harsh views as "This was an outrageous verdict," or "I felt the result of this case was a clear miscarriage of justice." Id. at 428-29. 
TABLE 5

The Effect of the Challenges, the Verdicts and the Judges' Reactions

\begin{tabular}{|c|c|c|c|c|}
\hline $\begin{array}{c}\text { Case } \\
\text { No. }\end{array}$ & $\begin{array}{c}\text { Shift in Probability } \\
\text { of a Guilty Verdict } \\
\text { Caused by the Challenges } \\
\text { (percentage points)* }\end{array}$ & $\begin{array}{c}\text { Verdict of } \\
\text { the Real } \\
\text { Jury }\end{array}$ & $\begin{array}{c}\text { "Verdict" } \\
\text { of the } \\
\text { Trial Judge }\end{array}$ & $\begin{array}{c}\text { The Trial Judge's } \\
\text { Evaluation of the } \\
\text { Verdict of the } \\
\text { Real Jury }\end{array}$ \\
\hline 1 & -18 & NG & G & "without merit" \\
2 & -2 & G & G & - \\
3 & +1 & NG & NG & - \\
4 & -30 & NG & G & "without merit" \\
5 & +3 & G & G & "tenable, for a jury" \\
6 & -13 & G & G & - \\
7 & +5 & G & G & - \\
8 & 0 & Hung & NG & (No Comment) \\
9 & 0 & G & G & "tenable, for a jury" \\
10 & +8 & NG & G & "without merit" \\
11 & -15 & NG & G & \\
12 & -72 & & &
\end{tabular}

- From Table 4, column 6.

Table 5 shows that the judges approved of all 5 convictions but disagreed with 5 of the 6 jury acquittals. ${ }^{28}$ In 2 of these cases (Cases 6 and 11), the judges regarded the verdict as "tenable for a jury"; in the other 3 (Cases 1, 4 and 12), the judges considered the verdict to be "without merit." Interestingly, these 5 cases had the greatest shifts in the probability of a guilty verdict as a result of the peremptory challenges. Furthermore, the 3 cases in which the judges felt the jury verdicts were "without merit" were the 3 with the greatest effects caused by peremptory challenges-Case $1(-18)$, Case 4 $(-30)$, and Case $12(-72)$.

This correlation between the effect of peremptory challenges and the degree of judge-jury disagreement in our sample does not permit us to conclude that peremptory challenges alone caused the severe judge-jury disagreements. In Case 12, the use of peremptory challenges changed the expected verdict from a conviction that the judge would have agreed with to an acquittal he characterized as "without merit," but in Cases 1 and 4, the most likely verdict of the reconstructed juries would have been an acquittal anyway. Thus, the peremptory challenges cannot totally explain why the verdicts reached in these 2 cases were characterized as "without merit" by the presiding judges.

28. The judge in Case 9, in which the jury hung, had no comment on the jury's verdict. 
A closer look at these 2 cases, however, reveals that both fall into categories that previous research has found foster jury acquittals when the judge would have convicted. The defendant in Case 1 was charged with draft evasion-the type of case in which jurors may have some sympathy with the crime committed. ${ }^{29}$ Case 4 was a misdemeanor trial for possession of a stolen television set valued at $\$ 50$-the type of offense clearly bearing the de minimis stamp that often moves jurors to acquit. ${ }^{30}$

Nevertheless, it is interesting that the judge, when pinning the "without merit" label on the verdicts in Cases 1, 4 and 12, could not have known that these 3 acquittals were brought in by juries whose propensity to acquit was increased by the use of peremptory challenges. Only the "retrospective clairvoyance" we gained through the experiment allowed us to make this connection. ${ }^{31}$.

Thus, our experiment suggests that judge-jury disagreements on verdicts must be explained by a combination of factors: the characteristics of the case and the effect of the peremptory challenges. As a result, our theory of why judge-jury disagreements occur must be amended. The American Jury found that two influences primarily accounted for these disagreements. Every so often, when the evidence is close to the borderline of reasonable doubtand even at times when it is clearly beyond the borderline-the jury that does not like the "letter of the law" may be guided by sentiments aimed at dispensing justice in the particular case. ${ }^{32}$ In addition, the jurors occasionally set for themselves a lower threshold than would the judge for the level of "reasonable doubt" that warrants acquittal. ${ }^{33}$ Both of these factors find their expression in the jury's crucial first ballot vote. Our results indicate that we now must add to these two reasons a third one: an occasional drastic shift in the first ballot constellation caused by the effective exercise of peremptory challenges.

29. Previous studies have shown that in such circumstances the jury's antipathy to prosecution of that offense often leads it to a verdict of not guilty even though the judge would have convicted. See H. KALVEN \& H. ZEISEL, supra note 17, at 286-305.

30. Id. at 258-85.

31. The coincidence in these three cases of the judge's disapproval and the effectiveness of the peremptory challenges has elements of "triangulation"-an evidentiary convergence that increases confidence in a result. See Campbell \& Fiske, Convergent and Discriminant Validation by the Multitrait-Multimethod Matrix, 56 Psychological Bull. 81 (1959). See generally Feigl, Existential Hypothesis: Realistic Versus Phenomenalistic Interpretations, 17 PHILosopHy ScI. 35 (1950).

32. H. KALVEN \& H. ZEISEL, supra note 17 , at 286-97.

33. Id. at $182-90$. 


\section{The "English Jury" and Experimental Bias}

As mentioned previously, ${ }^{34}$ the experimental design included a second shadow jury for each of the trials. Dubbed the "English jury," it was composed of members of the venire of prospective jurors who had watched the voir dire but had not undergone individual questioning. At first glance, the English jury would appear to be another standard against which we could compare the performance of the real jury. As it turned out, the English jurors were significantly more conviction-prone than the other members of the venire who went through the voir dire process and whose first ballot we learned or could estimate. ${ }^{35}$ The English jurors would have convicted the defendant in every case, even in the two cases in which the judge would have acquitted.

Table 6 shows that the cumulative first ballot vote of the English jurors differed significantly from that of the other group of jurors that had been randomly selected from the venire-the combined pool of the real jury plus the peremptorily excused jurors who had undergone voir dire.

TABLE 6

Experimental Bias of the "English Jury"

\begin{tabular}{|l|c|c|}
\cline { 2 - 3 } \multicolumn{1}{c|}{} & $\begin{array}{c}\text { "English } \\
\text { Jurors" }\end{array}$ & $\begin{array}{c}\text { Real and Peremptorily } \\
\text { Excused Jurors } \\
\text { Combined }\end{array}$ \\
\hline First Ballot Vote & $\%$ & $\%$ \\
Guilty & 80 & 64 \\
Not Guilty & 20 & 36 \\
\hline Total & $100 \%$ & $100 \%$ \\
Number of Jurors & $(109)$ & $(223)$ \\
\hline
\end{tabular}

Because the likelihood that a difference as large as this would occur by chance is less than 1 in $100,{ }^{36}$ we concluded that the English

34. See note 10 supra and accompanying text.

35. Even without this increased rate of conviction, the sampling error in such a small group would be too great to allow for a stable benchmark.

36. The Chi-Square statistic for these data is 8.35 , indicating a probability of less than .01 . Although the English jury did not contain anyone who had been excused for cause, it conceivably could contain some jurors who, had they undergone the voir dire questioning, would have been excused for cause. See note 14 supra. Even when conservative adjustments are made for this possibility, however, the difference presented in Table 6 remains significant. 
juries set a different threshold of reasonable doubt-a standard on which jurors are instructed to base their verdicts and which, in the end, jurors must define for themselves. The authors of The American Jury found that one of the mechanisms that occasionally contribute to the divergence between the jury's verdict and what the judge would have done $\mathrm{e}^{37}$ is a difference in the respective thresholds of reasonable doubt: Occasionally, the jury sets the demarcation at a lower level and acquits a defendant when the judge would have convicted.$^{38}$ It seems that the English jurors in our experiment had a higher reasonable doubt threshold than either the judge or the actual jury.

Although both the English jurors and those in the real jury were selected from the same venire, the English jurors differed in two important respects: None of the English jurors underwent the full voir dire questioning and none of them engaged in the jury deliberations that actually would lead to conviction or acquittal of the defendant. Either or both of these factors may have explained why the threshold of reasonable doubt was set so high by the English jurors. The personal questioning that occurs during the voir dire and the willingness of the attorneys and judge to retain a juror may leave an impact on the sitting jurors that was not experienced by the English jurors. This voir dire process may impress upon the jurors the importance of their task and may enhance their awareness of their duty to decide the case fairly and impartially. ${ }^{39}$ Alternatively, simply because the English jurors in our experiment were aware that the defendant's liberty was not in their hands, they may have raised their threshold of reasonable doubt-that is, they may have increased the amount of doubt needed to justify acquittal.

Because we do not know which of these factors may have accounted for the bias of the English jury, we must confront another, more serious question: If the English jury was more prone to convict simply because its verdict would not affect the actual trial participants, might not this same bias also have affected the peremptorily excused jurors who sat as shadow jurors in our experiment? Although the excused jurors were individually questioned, they too

37. For a more complete discussion of judge-jury disagreements, see text accompanying notes 27-33 supra.

38. H. KALVEN \& H. ZeISEL, supra note 17, at 182.

39. There is some evidence to support this contention from experiments with simulated juries. See, e.g., Singer, Singer \& Singer, Voir Dire by Two Lawyers: An Essential Safeguard, 57 JUDICATURE 386, 391 (1974). 
were aware that their verdict would not determine the outcome of the trial.

A number of considerations suggest that the excused jurors were not so tainted. The best evidence in support of this position is provided by Table 7, which shows the breakdown of the first ballot votes of the real and the peremptorily excused jurors.

\section{TABLE 7}

Average First Ballot Vote of Real and Excused Jurors

\begin{tabular}{|l|c|c|c|}
\cline { 2 - 4 } \multicolumn{1}{c|}{} & $\begin{array}{c}\text { Real } \\
\text { Jurors }\end{array}$ & $\begin{array}{c}\text { Excused } \\
\text { Jurors }\end{array}$ & Total \\
\hline Guilty & $\%$ & $\%$ & \\
Not Guilty & 61 & 66 & 63 \\
\hline Total & 39 & 34 & 37 \\
Number of Jurors & $100 \%$ & $100 \%$ & $100 \%$ \\
\hline
\end{tabular}

The excused jurors produced essentially the same proportion of guilty votes $(66 \%)$ as the real jurors $(61 \%) .{ }^{40}$ By itself, this result is not proof of lack of bias, because the two groups of jurors are not strictly comparable. But it is this very absence of comparability that strengthens the final conclusion. The method of selecting the excused jurors, if anything, should have increased the proportion of guilty votes: The defense excused nearly twice as many jurors (54) as the prosecution (31), and, as we shall show in the next section, ${ }^{41}$ the defense on the whole did a better job of finding its target-the jurors who would vote guilty-than did the prosecution. In spite of this twofold expectation of a larger proportion of guilty votes among the excused jurors, Table 7 demonstrates that they differed only slightly from the real jurors in their propensity to convict. We therefore conclude that the excused jurors do not share the higher conviction-proneness of the English jury.

\section{E. The Attorneys' Ability to Detect Hostile Jurors}

Our data gave us some idea of how well the attorneys used their allotted challenges to excuse jurors who, had they been allowed to sit

40. The Chi-Square value is .57 , indicating a chance distribution.

41. See Table 9 and text accompanying notes $42-49$ infra. 
on the jury, would have voted against their side. We designed a rough performance index that evaluated the extent to which counsel employed peremptory challenges to dismiss hostile or friendly jurors. ${ }^{42}$ Table 8 illustrates the calculation of the index for the prosecutor's performance in Case 10.

\section{TABLE 8}

\section{Evaluation of Prosecutor's Use of Peremptory Challenges in Case 10}

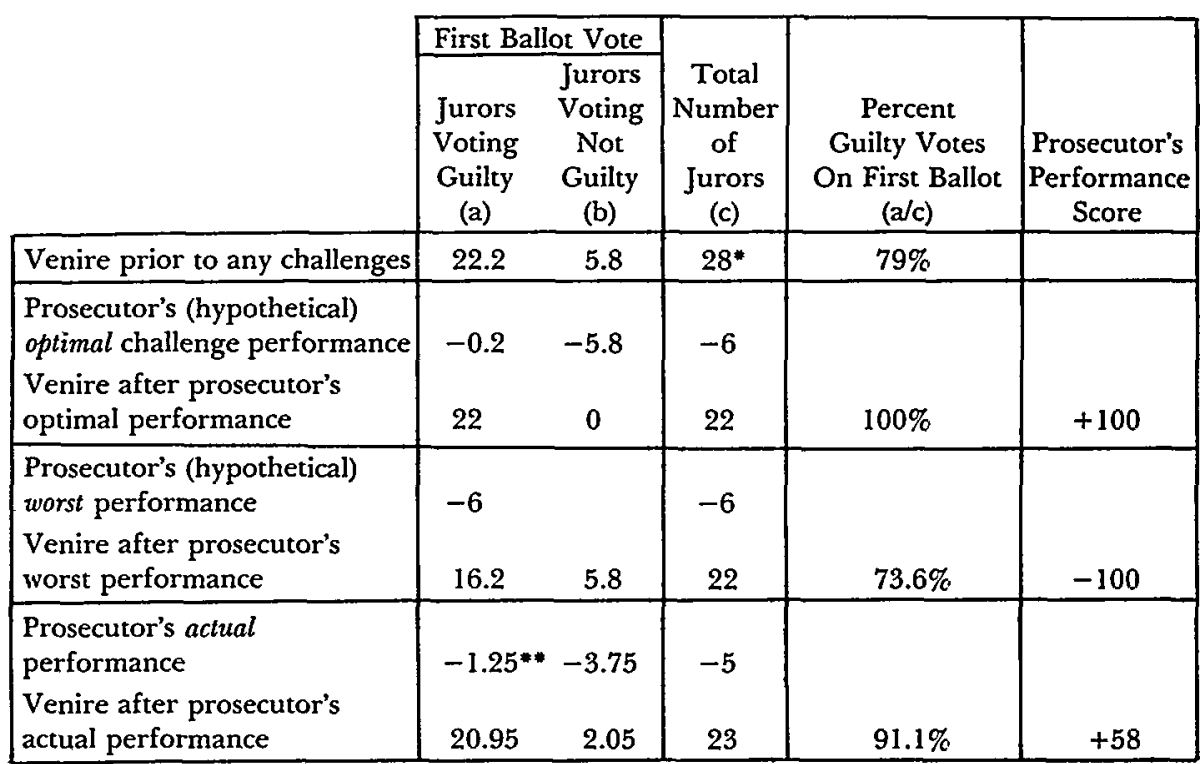

* The members of the venire whom the prosecutor would have had an opportunity to challenge at voir dire if both attorneys had exercised all their challenges.

** The fraction emerged as follows: The prosecutor excused a total of 5 jurors, but we knew the first ballot vote only for 4 of the 5 . We apportioned the "unknown" vote in the ratio of 1 to 3 (.25 to .75) according to the known vote of the 4 jurors. See Table 3.

42. This index provides only an approximate measure of attorney performance because it does not take three factors into account. First, it assumes that all potential jurors are examined at one time, and that the prosecution makes all of its challenges before the defense makes any; in the present trials, potential jurors were examined individually and challenges were made in stages. See text accompanying notes 6-8 supra. It should be noted, however, that many courts, both federal and state, arrange the challenge procedure so that each side "strikes" jurors from the list, very much as our model assumes. This procedure was used in the Mitchell-Stans trial. See note 49 infra. Second, our index ignores the possibility that attorneys may be faced with the choice between saving one of a limited number of challenges, and thus accepting a juror who may be unfavorable to their side, or exercising that challenge, thereby risking having later to accept someone who seems even more unfavorable. See note 18 supra.

Third, our index is calculated as if the attorneys exercised all their challenges. However, because a jury may be impaneled before the attorneys exhaust their peremptory challenges, 
The original venire consisted of 28 potential jurors, of whom 22.2 would have voted guilty and 5.8 not guilty. ${ }^{43}$ The prosecutor's "best performance," therefore, would have used the allotted 6 peremptory challenges to eliminate all 5.8 jurors voting not guilty; $100 \%$ of the remaining jurors would have voted guilty. In formulating our attorney performance index, we would have assigned this optimal performance a score of +100 . The prosecutor's "worst performance" would have excluded 6 guilty-voting jurors, leaving the proportion of guilty votes at $\mathbf{1 6 . 2}$ out of 22 , or $73.6 \%$; this worst possible performance would have been assigned a score of -100 . A zero score would represent a performance leaving unchanged the original distribution of the venire, estimated at $79 \%$ guilty votes.

In the actual case (Case 10), the prosecutor selected his jurors so as to leave a voting constellation of $91.1 \%$ guilty votes. We therefore computed this prosecutor's score as follows: (1) because the prosecutor increased the proportion of favorable jurors, the score was given a positive value; (2) the absolute value then was measured by calculating the difference between the percentage of guilty votes in the original venire (79) and the percentage of guilty votes after the prosecutor's challenges (91.1), a score of 12.1 ; (3) this value then was normalized by dividing by the maximum possible improvement (the difference between the guilty percentage at a zero score, 79, and the

the attorneys may face fewer potential jurors than is theoretically possible. The justification for this assumption, which was necessary because we needed a common denominator, is twofold. First, in each of the cases used in the experiment, optimally performing attorneys would have used nearly all of their challenges. Second, the attorney performance index has value only as a relative index, and thus, the base standard chosen is not crucial so long as it is applied consistently.

43. We established this distribution of first ballot votes in the standardized 28-person venire by determining the proportion of guilty votes among the potential jurors questioned during voir dire. In Case 10, for example, we were allowed to discover directly the first ballot vote of the actual jury, which was 11 to $I$ for conviction. We also knew that all 6 of the potential jurors the defense challenged would have voted to convict, and that among the 5 potential jurors dismissed by the prosecution 1 would have voted to convict and 3 to acquit. The remaining potential juror dismissed by the prosecution did not participate in our study. As demonstrated in Table 3 , that potential juror's vote was estimated by the ratio of votes of those potential jurors dismissed by the prosecution who did participate in the study. They voted 1 to 3 to convict, so the missing vote was allocated in a 1 to 3 ratio: .25 to convict, .75 to acquit. By adding the guilty votes of the actual, potential and missing jurors, we determined that $18.25(11+6+1+.25)$ or $79 \%$ of the actual panel would have voted for conviction. Presumably, any size panel chosen by the same standards would contain the same percentage of guilty votes. We needed to hypothesize a 28 -person panel to account for the challenges that were not exercised. Because $79 \%$ of 28 is 22.2 , we established that figure as the number of guilty votes in the standardized 28-person venire. The difference between 28 and 22.2, 5.8, was designated as the number of not guilty votes in the 28 -person venire. 
guilty percentage at a +100 score, 100). The resulting ratio, $+12.1 / 21$, expressed as a percentage, +58 , became the prosecutor's performance score. ${ }^{44}$

To complete the attorney performance index, we performed parallel computations for the prosecution and defense counsel in each of the 12 cases. ${ }^{45}$ Table 9 presents the results of these calculations.

TABLE 9

Attorney Performance Index

\begin{tabular}{|c|c|c|}
\hline Case No. & Prosecutor & Defense \\
\hline 1 & +23 & +46 \\
2 & -59 & +6 \\
3 & +44 & +30 \\
4 & -20 & +44 \\
5 & +31 & +48 \\
6 & -61 & -11 \\
7 & +9 & -10 \\
8 & -32 & -62 \\
9 & $0 *$ & +12 \\
10 & +58 & +46 \\
11 & +62 & +36 \\
12 & -61 & +19 \\
\hline Average (Mean) & -0.5 & +17.0 \\
\hline Around the Mean & \pm 38 & \pm 25 \\
\hline
\end{tabular}

- The prosecutor exercised only one challenge, and the challenged juror did not participate in the study. See note 19 supra.

44. If the prosecutor in Case 10 had instead decreased the proportion of favorable jurors through the use of peremptory challenges, our procedure would have differed in two ways. First, because the peremptory challenges left the prosecutor in a poorer position than if he had not exercised any challenges, he would have been assigned a negative rather than a positive value. Second, we would have normalized the score by comparing the shift away from the configuration of guilty votes at a zero score-the shift caused by the "unwise" exercise of peremptory challenges to exclude favorable jurors-with the worst possible result from the prosecutor's point of view (the guilty percentage at a -100 score, 73.6).

45. The basic calculations for the defense differ to the extent that the defense could exercise a minimum of 10 peremptory challenges, whereas the prosecution was limited to 6 , except in the one case in which both sides were granted only 3 challenges. Furthermore, the pool of potential jurors to which a defense attorney can be exposed is 22: 28 venire members minus the 6 who might be removed by the prosecutor. 
The collective performance of the attorneys is not impressive. The prosecutors' average score is close to zero $(-0.5)$. Thus, in the aggregate, the prosecutors made about as many good challenges as bad ones. The defense counsel's average performance score $(+17.0)$ is slightly better, which suggests that, on the average, defense attorneys shifted in their favor the proportion of not guilty votes in the venire. These averages are misleading, however, because the fluctuations around them are so large. The prosecutors' scores fluctuate between +62 (Case 11) and -61 (Cases 6 and 12); the defense counsel's scores fluctuate between +48 (Case 5) and -62 (Case 8). The average fluctuations around the mean scores are \pm 38 for the prosecutor and \pm 25 for the defense, suggesting that in this limited sample of 12 cases, attorney performance was highly erratic. As a result, even though attorneys' scores on the average were around zero, in some cases the attorneys performed very poorly, and in others very well. And if, in a case, one side performs poorly while the other side performs well, such disparity may have interesting results.

There is a correspondence between those cases that Table 4 indicates had the greatest shifts in the probability of a given jury verdict and those cases in which, as Table 9 shows, the difference between levels of attorney performance was greatest. In Cases 1, 4 and 12-the cases in which the effects of voir dire on jury verdicts were most pronounced-the shifts in the likelihood of a guilty verdict are related to differential levels of attorney performance. Case 12, for example, showed the most dramatic shift in the probability of a guilty verdict (-72); it was also the case in which attorney performance differed the most. The prosecutor had a marked negative score $(-61)$, while the defense attorney had a performance score that was noticeably positive $(+19)$. In Cases 1 and 4 , where the respective shifts in probability were -18 and -30 , differences between the performance levels of opposing counsel similarly occur. ${ }^{46}$

46. As Case 11 shows, the indices for prosecution and defense are not strictly comparable. Because defense attorneys have more challenges, they may eliminate as many hostile jurors as the prosecutor (in Case 11 each eliminated 2 hostile jurors) yet still receive a lower score because defense counsel might have used the extra challenges to eliminate more hostile jurors than the prosecutor.

In Cases 2 and 8 , there were noticeable differences in the performance scores of the attorneys as well, yet the probability of guilty verdicts was affected very little. In neither of these cases, however, were there more than 2 potential jurors who would have voted for acquittal. Had both been eliminated, the probability of conviction would have been $100 \%$, but even if the prosecution performed as badly as possible and the defense performed as well as 
The present analysis does not take up the complex task of discovering why some attorneys performed better than others. We do not know how much of their performance was the result of superior skill $^{47}$ or of luck or simply of easier choices. Nor do we know to what extent the ever-shrinking information that becomes available during voir dire contributes to that differential performance. ${ }^{48}$ But whatever the reasons, the generally poor and occasionally disparate performances of the prosecutor and defense counsel raise questions concerning the role of peremptory challenges in furthering the constitutionally prescribed goal of trial by an impartial jury. ${ }^{49}$ The following Part of the Article discusses this larger issue.

\section{Discussion}

The first conclusion emerging from this study is that there are cases in which the jury verdict is seriously affected, if not deter-

possible, the first ballot vote still would have been at least 10 to 2 for conviction; Graph 1 reveals that in such cases the jury will convict $95 \%$ of the time. Any change in the first ballot vote caused by a realignment of votes in the jury through peremptory challenges can have only a small effect on the ultimate outcome when the venire strongly favors one side.

47. To answer this question, it would be necessary to show whether particular attorneys can eliminate unfavorable jurors, with some consistency.

48. See note 66 infra and accompanying text.

49. There is a growing body of literature on the methods employed by attorneys to improve their performances at voir dire. See, e.g., A. Ginger, JURY SELECTION IN CRIMINAL. Trials: New Techniques and Concepts (1975); The JuRY System: New Methods for Reducing PRejudice (D. Kairys ed. 1975). Attorneys have attempted to supplement the knowledge about prospective jurors they have gained by their own experience and intuition by using scientific discovery methods, and social scientists have been enlisted to assist attorneys in developing profiles of "good" and "bad" jurors. There are two basic types of juror profiles: personality, or clinical, profiles and demographic profiles. See A. GINGER, supra §§ 11.9-.11. The utility of such profiles varies, however, depending on the difficulty of establishing distinguishing characteristics in the population and recognizing the criteria in the potential jurors presented for voir dire. For example, personality profiles are found to be less useful in federal trials than in state trials because attorneys in federal trials are less free to direct the questioning of potential jurors to areas that will reveal crucial personality traits. See E. DEvITT \& C. BLACKMAR, supra note $6, \S 3.01$.

Juror selection techniques, however, can provide only general guidelines and are far from infallible, as was demonstrated in the Harrisburg trial of Father Berrigan, in which the mother of four conscientious objectors surprisingly held out for conviction. See J. NELSON \& R. Ostrow, ThE FBI AND THE BERRIGans 297 (1972). Included in the list of pertinent literature on this subject are: Schulman, Shaver, Colman, Emrich \& Christie, Recipe for a Jury, Psych. TODAy, May 1973, at 37; Kahn, Picking Peers: Social Scientiss' Role in Selection of Juries Sparks Legal Debate, Wall St. J., Aug. 12, 1974, at 1, col. 1; McConahay, Mullin \& Fredrick, The Uses of Social Science in Trials with Political and Racial Overtones: The Trial of Jo Ann Little (Mimeograph Working Paper, Center for Political Analysis, Duke University). For a critical review of these developments, see Babcock, supra note 6, at 559-63; Zeisel \& Diamond, The Jury Selection in the Mitchell-Stans Conspiracy Trial, 1976 AM. B. FOUNDATION RESEARCH J. 151, 169. 
mined, by the voir dire. At times, one attorney will significantly outperform the opposing attorney in challenging hostile jurors. Lawyers apparently do win some of their cases, as they occasionally boast, during or at least with the help of, voir dire.

We have no firm basis from which to estimate how often this occurs. The 12 cases used in the experiment do not constitute a probability sample. Moreover, the unusually low incidence of judgejury agreement in these cases suggests a biased sample. ${ }^{50}$ We have no reason to believe, however, that the method employed to select the trials used in the experiment led to the selection of cases in which the opportunity to influence the verdict by the exercise of peremptory challenges was greater than normal. We are, therefore, tentatively persuaded that cases in which peremptory challenges have an important effect on the verdict occur with some frequency.

In the 5 cases in which we detected significant shifts as a result of peremptory challenges, the shifts benefited the defense. What caused the shifts in favor of the defense? First, the defense attorneys performed better than the prosecutors: Their average score was better- +17.0 compared to -0.5 for prosecutors-and they outperformed their adversaries in 8 of the 12 cases. Second, because more challenges are allotted to the defense than to the prosecution, we must explore the extent to which this imbalance is likely to benefit the defense. This question requires a more general explanation of how jury verdicts can be affected by the various combinations of good and poor performance of the two attorneys at voir dire.

\section{A. The Potential Impact of the Peremptory Challenge}

In noncapital felony cases, federal rules presently give the prosecution 6 peremptory challenges and the defense 10.51 Apart from potential jurors dismissed for cause, an attorney therefore can confront as many as 28 veniremen: the 12 who actually serve, the 10 the defense can dismiss and the 6 the prosecution can dismiss. If each of these 28 potential jurors were to sit through the trial and vote on the first ballot, 29 combinations of guilty and not-guilty votes would be possible. These 29 combinations, ranging from 28 guilty-votes to 28 not guilty votes, would reflect the strength or weakness of the particular case tried before that jury. In Table 10, we show the

50. In $50 \%$ of the cases in this experiment, the judge agreed with the jury's verdict. See Table 5. Previous research has indicated that, on the average, the judge and jury will agree in $69 \%$ of the cases. See H. KALVEN \& H. ZEISEL, supra note 17, at 58; note 27 supra.

51. Fed. R. Crim. P. 24(b). See note 8 supra. 
changes in the first ballot voting that would occur if both attorneys performed optimally, challenging as many hostile jurors as their allotment of challenges allows.

TABLE 10

Shift in First Ballot Constellation Through Peremptory Challenges (Prosecution and Defense Perform Optimally)

\begin{tabular}{|c|c|c|c|c|c|c|c|}
\hline \multicolumn{3}{|c|}{$\begin{array}{c}\text { First Ballot } \\
\text { Constellations in } \\
\text { Venire Before Challenges }\end{array}$} & \multicolumn{2}{|c|}{$\begin{array}{l}\text { Venire } \text { After } \\
\text { Prosecution } \\
\text { Challenges } \\
\text { (up to } 6 \text { jurors) }\end{array}$} & \multicolumn{3}{|c|}{$\begin{array}{c}\text { Venire After } \\
\text { Both Prosecution and } \\
\text { Defense Challenges } \\
\text { (Defense up to } 10 \text { jurors) }\end{array}$} \\
\hline Guilty & $\begin{array}{c}\text { Not } \\
\text { Guilty }\end{array}$ & $\begin{array}{c}\text { Percent } \\
\text { Guilty }\end{array}$ & Guilty & $\begin{array}{l}\text { Not } \\
\text { Guilty }\end{array}$ & Guilty & $\begin{array}{c}\text { Not } \\
\text { Guilty }\end{array}$ & $\begin{array}{c}\text { Percent } \\
\text { Guilty }\end{array}$ \\
\hline 0 & 28 & 0 & 0 & 22 & 0 & 22 & 0 \\
\hline 1 & 27 & 4 & 1 & 21 & 0 & 21 & 0 \\
\hline 2 & 26 & 7 & 2 & 20 & 0 & 20 & 0 \\
\hline 3 & 25 & 11 & 3 & 19 & 0 & 19 & 0 \\
\hline 4 & 24 & 14 & 4 & 18 & 0 & 18 & 0 \\
\hline 5 & 23 & 18 & 5 & 17 & 0 & 17 & 0 \\
\hline 6 & 22 & 21 & 6 & 16 & 0 & 16 & 0 \\
\hline 7 & 21 & 25 & 7 & 15 & 0 & 15 & 0 \\
\hline 8 & 20 & 29 & 8 & 14 & 0 & 14 & 0 \\
\hline 9 & 19 & 32 & 9 & 13 & 0 & 13 & 0 \\
\hline 10 & 18 & 36 & 10 & 12 & 0 & 12 & 0 \\
\hline 11 & 17 & 39 & 11 & 11 & 1 & 11 & 8 \\
\hline 12 & 16 & 43 & 12 & 10 & 2 & 10 & 17 \\
\hline 13 & 15 & 46 & 13 & 9 & 3 & 9 & 25 \\
\hline 14 & 14 & 50 & 14 & 8 & 4 & 8 & 33 \\
\hline 15 & 13 & 54 & 15 & 7 & 5 & 7 & 42 \\
\hline 16 & 12 & 57 & 16 & 6 & 6 & 6 & 50 \\
\hline 17 & 11 & 61 & 17 & 5 & 7 & 5 & 58 \\
\hline 18 & 10 & 64 & 18 & 4 & 8 & 4 & 67 \\
\hline 19 & 9 & 68 & 19 & 3 & 9 & 3 & 75 \\
\hline 20 & 8 & 71 & 20 & 2 & 10 & 2 & 83 \\
\hline 21 & 7 & 75 & 21 & 1 & 11 & 1 & 92 \\
\hline 22 & 6 & 79 & 22 & 0 & 12 & 0 & 100 \\
\hline 23 & 5 & 82 & 23 & 0 & 13 & 0 & 100 \\
\hline 24 & 4 & 86 & 24 & 0 & 14 & 0 & 100 \\
\hline 25 & 3 & 89 & 25 & 0 & 15 & 0 & 100 \\
\hline 26 & 2 & 93 & 26 & 0 & 16 & 0 & 100 \\
\hline 27 & 1 & 96 & 27 & 0 & 17 & 0 & 100 \\
\hline 28 & 0 & 100 & 28 & 0 & 18 & 0 & 100 \\
\hline
\end{tabular}


At the two extremes, the venire members are unanimous in favoring one side or the other, and any 12 jurors selected from these venires would either all convict or all acquit; peremptory challenges can have no effect in these two situations. When the number of potential jurors who would vote not guilty does not exceed 6 , the prosecution has the power to remove all of them, thus leaving a venire with no prospective jurors who would vote not guilty. Similarly, optimal use of the 10 challenges available to the defense serves to eliminate all opposition where the initial venire has no more than 10 jurors who would vote guilty. The effects of optimal use of peremptory challenges on the intermediate constellations vary, but when the venire is closely divided, the present allocation of peremptory challenges offers a significant advantage to the defense. Table 10 reveals that whenever the venire has fewer than 18 individuals who would vote to convict, the defense's 4 extra peremptory challenges allow it to face a jury with proportionately fewer guilty votes than were in the original venire.

The shifts shown in Table 10, however, presume optimal attorney performance, and our experiment suggests that in practice attorneys do not perform optimally. ${ }^{52}$ Therefore, Graph 2 illustrates the effects of various combinations of attorney performance on the likelihood of a guilty verdict. We have matched the optimal, neutral and worst possible performances of each of the sides, yielding nine possible pairings: When the prosecution performs optimally $(\mathrm{P}+)$, it may meet with the defense's optimal performance $(\mathrm{P}+\mathrm{D}+)$, its neutral performance $(\mathrm{P}+\mathrm{Do})$ or its worst performance $(\mathrm{P}+\mathrm{D}-)$. Likewise, the neutral performance on the part of the prosecution (Po) may meet with the optimal $(\mathrm{PoD}+)$, neutral (PoDo) or worst (PoD-) performance of the defense. Finally, the worst performance of the prosecution $(\mathrm{P}-)$ also can meet with the optimal $(\mathrm{P}-\mathrm{D}+)$, neutral $(\mathrm{P}-\mathrm{Do})$ or worst $(\mathrm{P}-\mathrm{D}-)$ performance of the defense.

The 9 lines in Graph 2 represent different attorney performance combinations. Each line relates the possible first ballot voting constellation in the venire (plotted on the horizontal axis) to the resulting first ballot constellation in the jury (plotted on the vertical axis). As an example, consider the $\mathrm{P}+\mathrm{D}+$ performance combination. This line, which represents optimal performance by both attorneys, begins like all the others in the lower left-hand corner of the graph and

52. See text accompanying notes $45-49$ supra. 
GRAPH 2

Opportunity for Change in the Jury's First Ballot Constellation Under the Present Federal Rules

\% No.

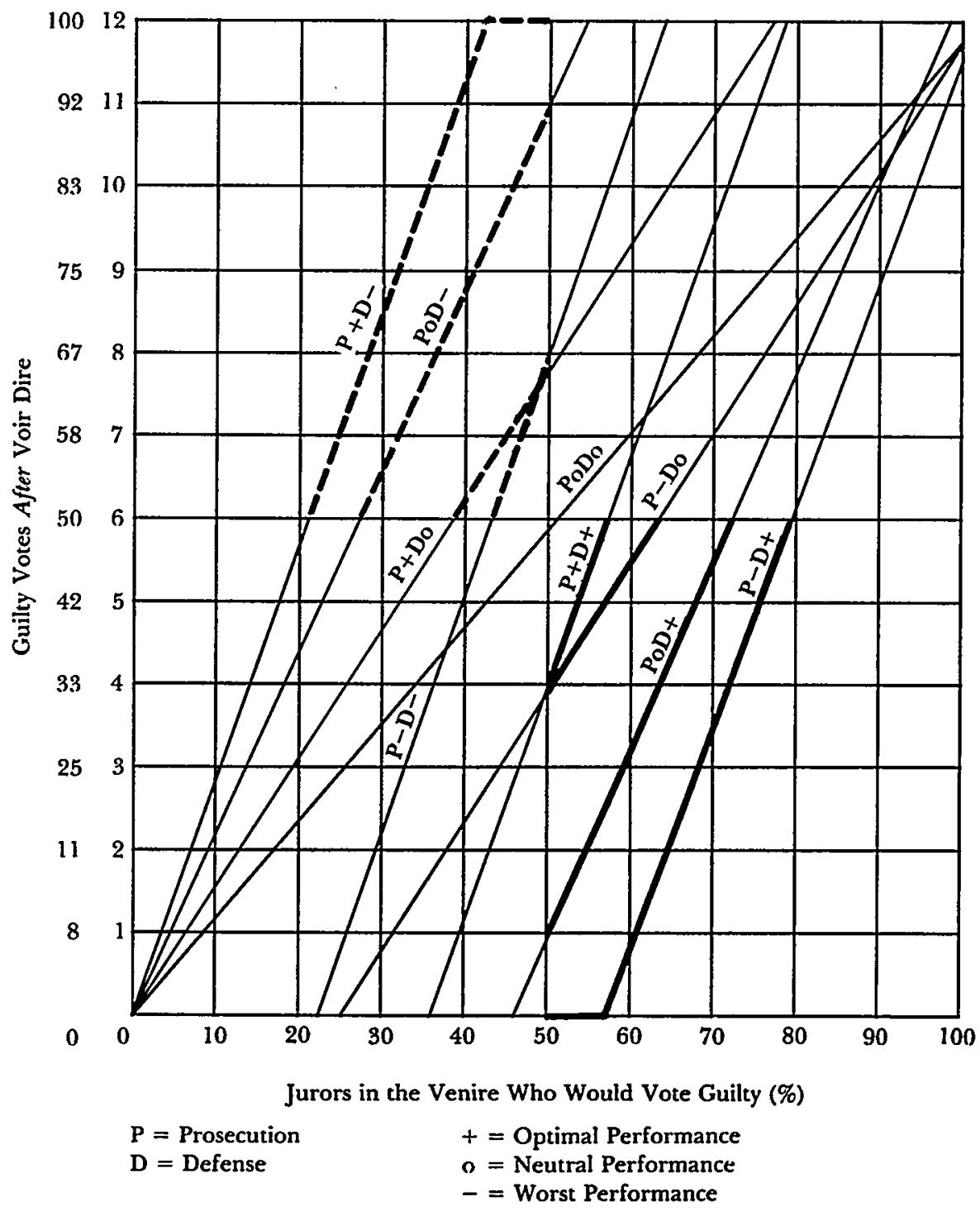


ends in the upper right-hand corner. The first section of this $\mathrm{P}+\mathrm{D}+$ line-that part lying on the horizontal line between the origin and 36-indicates that when there are fewer than 10 persons in the 28 -person venire $(36 \%)$ who would cast guilty votes on the first ballot, the effect of the optimal use of challenges by the defense will be to eliminate all guilty votes from the final jury verdict. The final section of the line begins where 22 or more of those in the 28person pool (79\%) would vote for conviction. Here, the prosecution's optimal use of its 6 challenges would remove all hostile members of the venire from the jury. The middle section of the $P+D+$ line, the segment sloping upwards from the bottom of the graph, shows the constellation of guilty votes in the final jury in situations in which neither the defense nor the prosecution by optimal use of its challenges can dismiss all hostile members of the venire. Thus, for any first ballot constellation in the venire, we can read the expected first ballot vote in the final jury. For example, if half the venire would vote guilty, we observe that optimal use of peremptory challenges by both sides will result in a jury with only four guilty votes.

Because the defense has four more peremptory challenges than the prosecution, it has a significant advantage when both sides use their challenges optimally or when the defense performs better than the prosecution. The importance of this advantage becomes more apparent when first ballot votes are converted by the use of Graph 1 into the probability of an ultimate guilty verdict. For example, assuming optimal performance, if the venire is split 16-12 in favor of conviction, the relation between the first ballot votes and the verdict indicates that a similarly proportioned jury would find the defendant guilty nearly $70 \%$ of the time. ${ }^{53}$ After optimal exercise of peremptory challenges by both attorneys, however, the likelihood of conviction decreases to less than $45 \%$. Similarly, if the venire is divided $15-13$, the corresponding percentages shift from $60 \%$ to less than $25 \%$, and if the venire is split evenly, the percentages change from $45 \%$ to $10 \%$.

The dark lines in Graph 2 indicate those areas in which peremptory challenges have changed a probable conviction by the venire into a probable acquittal by the actual jury. The dotted lines, on the other hand, show where probable acquittals become probable convictions. Table 11 extracts from Graph 2 those areas in which various combinations of attorney performance are likely to cause differences in the votes of the final jury and the original venire.

53. See Graph 1; notes 21-24 supra and accompanying text. 


\section{TABLE 11}

Zones in Which the Peremptory Challenges Reverse the First Ballot Majority Constellations

\begin{tabular}{|c|c|c|c|c|c|c|c|c|c|}
\hline & \multicolumn{9}{|c|}{ Performance Combinations } \\
\hline & 1 & 2 & 3 & 4 & 5 & 6 & 7 & 8 & 9 \\
\hline Prosecution $(\mathrm{P})$ & 0 & + & - & + & - & 0 & - & + & 0 \\
\hline Defense (D) & 0 & + & - & 0 & 0 & + & + & - & - \\
\hline $\begin{array}{l}\text { A majority for gritly in } \\
\text { the venire will be re- } \\
\text { versed into a majority } \\
\text { for acquittal if the } \\
\text { original proportion of } \\
\text { votes in the venire was } \\
\text { between }\end{array}$ & - & $\begin{array}{c}51 \% \\
-56 \% \\
(5 \mathrm{pts})\end{array}$ & - & - & $\begin{array}{c}51 \% \\
-57 \% \\
\text { (6 pts) }\end{array}$ & $\begin{array}{c}51 \% \\
-70 \% \\
(19 \mathrm{pts})\end{array}$ & $\begin{array}{c}51 \% \\
-77 \% \\
\text { (26 pts) }\end{array}$ & - & - \\
\hline $\begin{array}{l}\text { A majority for nequitsal } \\
\text { in the venite will be re- } \\
\text { yeried into a majon ity } \\
\text { for guilty, if the ori- } \\
\text { ginal proportion of } \\
\text { guilty votes was be- } \\
\text { incen }\end{array}$ & - & - & $\begin{array}{c}43 \% \\
-49 \% \\
(6 \mathrm{pts})\end{array}$ & $\begin{array}{c}39 \% \\
-49 \% \\
(10 \mathrm{pts})\end{array}$ & - & - & - & $\left|\begin{array}{c}21 \% \\
-49 \% \\
(28 \mathrm{pts})\end{array}\right|$ & $\begin{array}{c}27 \% \\
-49 \% \\
(22 \mathrm{pts})\end{array}$ \\
\hline
\end{tabular}

Graph 2 and Table 11 address the potential effects of differential attorney performance under a rule that allocates 6 peremptory challenges to the prosecution and 10 to the defense. ${ }^{54}$ Table 11 highlights these effects by delimiting those instances in which the attorneys, by use of peremptory challenges, can change the expected verdict. In other words, it shows the range of first ballot constellations in the original venire for which an attorney can use the peremptory challenges to shift what would likely be a losing verdict to a winning one. Table 8 reveals that when both attorneys perform equally (columns 1, 2 and 3), there is little chance of reversing the expected verdict. If the defense counsel performs neutrally (columns 4 and 5), the reversal range is still modest (only 6 or 10 percentage points), regardless of the prosecutor's performance. When the roles are reversed, however-that is, when the prosecutor exercises challenges neutrally-the potential reversal range doubles (to 19 or 22 percentage points). Not surprisingly, the maximum likelihood of changing the expected verdict occurs when the attorneys perform at opposite extremes (columns 7 and 8). Finally, because of the imbalance in the number of available challenges, the performance of the defense counsel (whether good or

54. See note 8 supra. 
poor) generally will have a greater potential effect than that of the prosecutor.

In the next section, we examine the arguments for unequal allocation of challenges and, in light of our experimental findings, the utility of the peremptory challenge system in practice.

\section{B. Using Peremptory Challenges to Obtain an Impartial Jury}

The primary function of the voir dire is elimination from the venire of those potential jurors prejudiced or biased in favor of either the prosecution or the defense. ${ }^{55}$ Graph 3 presents a hypothetical distribution of prejudice in the venire of prospective jurors. In this model, we assume that bias is symmetrically distributed and that it varies from an extreme pro-prosecution orientation, favoring conviction, to a similarly extreme pro-defense predisposition, favoring acquittal; the majority of prospective jurors lie somewhere between the two extremes, around the no-bias point.

Ideally, it is the court's responsibility to excuse for cause those jurors with extreme prejudice-those depicted in the dark areas in Graph 3. And we may see it as a function of the peremptory challenge to remove the less patently prejudiced prospective jurors, those in the shaded areas. The unchallenged jurors remain. They are not free of prejudice, but the level of bias is low. These remaining jurors are the realistic approximation to the ideal of the "fair and impartial jury." 56

55. See Babcock, supra note 6 , at 549-52. Some authorities suggest that voir dire serves a function in addition to that of qualifying unbiased jurors. Professors Amsterdam and Kaplan, for example, note that because attorneys use the voir dire as a vehicle to speak directly with jurors, it performs the important task of educating the jurors as to the meaning of "reasonable doubt." See A. AMSTERdaM, B. Segal \& M. Miller, supra note 2, §§ 337-39; J. KAPLAN \& J. WALTZ, THE TRIAL OF JACK RUBY 91-94 (1965). However, as Professor Kaplan notes, despite this educational role, the "main and, in theory, . . . only legitimate function [of voir dire is] developing sufficient information upon which to select the jurors." Id. at 92 . Both because of the primary importance of voir dire as a procedure to qualify unbiased jurors and because this study is based upon data from the federal court system (where attorneys are permitted to ask questions during the voir dire only at the judge's discretion), we have not focused on the educational justifications for voir dire. Rather, we have limited our study to an examination of the role of voir dire in altering the distribution of prejudice in a venire and thus affecting the ultimate jury verdict.

56. The sixth amendment declares that "[i]n all criminal prosecutions, the accused shall enjoy the right to a speedy and public trial, by an impartial jury of the State and district wherein the crime shall have been committed." U.S. CONST. amend. VI (emphasis added). The Supreme Court has recognized, however, that requiring that jurors lack any preconceived notions about the trial would set an "impossible standard," Irvin v. Dowd, 366 U.S. 717, 723 (1961), and that a juror's "qualifications as to impartiality" must merely fall within "minimum. standards," Beck v. Washington, 369 U.S. 541, 557 (1962). 


\section{GRAPH 3 \\ Distribution of Prejudice Within the Venire}

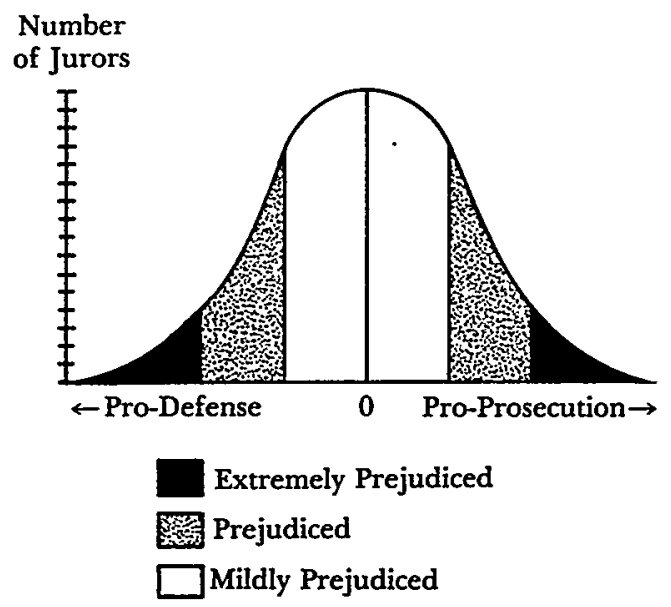

For the sake of simplicity, this model assumes that prejudice is distributed symmetrically in the venire. This may well be an unjustified assumption; one-sided pretrial publicity ${ }^{57}$ or more firmly rooted community prejudices-against blacks or homosexuals, for example ${ }^{58}$-often may produce asymmetry in the distribution of bias. Furthermore, the distribution is likely to vary in the degree of prejudice that potential jurors may hold. The variance of the distribution may be small, in which case a large proportion of the venire will be grouped around the no-bias point, or the variance may be large, in which case there will be a greater number of potential jurors harboring extreme prejudices.

Graph 4 shows how these two factors-symmetry and variancecombine to form four potential distributions of prejudice in the venire..$^{59}$

57. See Borcher, Fair Trial \& Free Press: Preliminary Hearing - Gateway to Prejudice, 1975 LAW \& SOC. ORD. 903.

58. Cf. Ham v. South Carolina, 409 U.S. 524, 527 (1973) (due process requires interrogation of jurors on subject of racial prejudice when party so demands). See generally Blauner, The Sociology of Jury Selection, in A. GINGER, supra note 49, §§ 10.6-.8.

59. We have assumed for the sake of example in Graph 4 and the following analysis that the asymmetrical distributions are positively skewed towards the prosecution-that is, that a majority of the venire will have a pro-prosecution orientation. An assumption that the underlying population favors the defense, however, would lead to exactly opposite effects of, and solutions to, the skewness. 


\section{GRAPH 4}

Four Distributions of Prejudice in the Venire

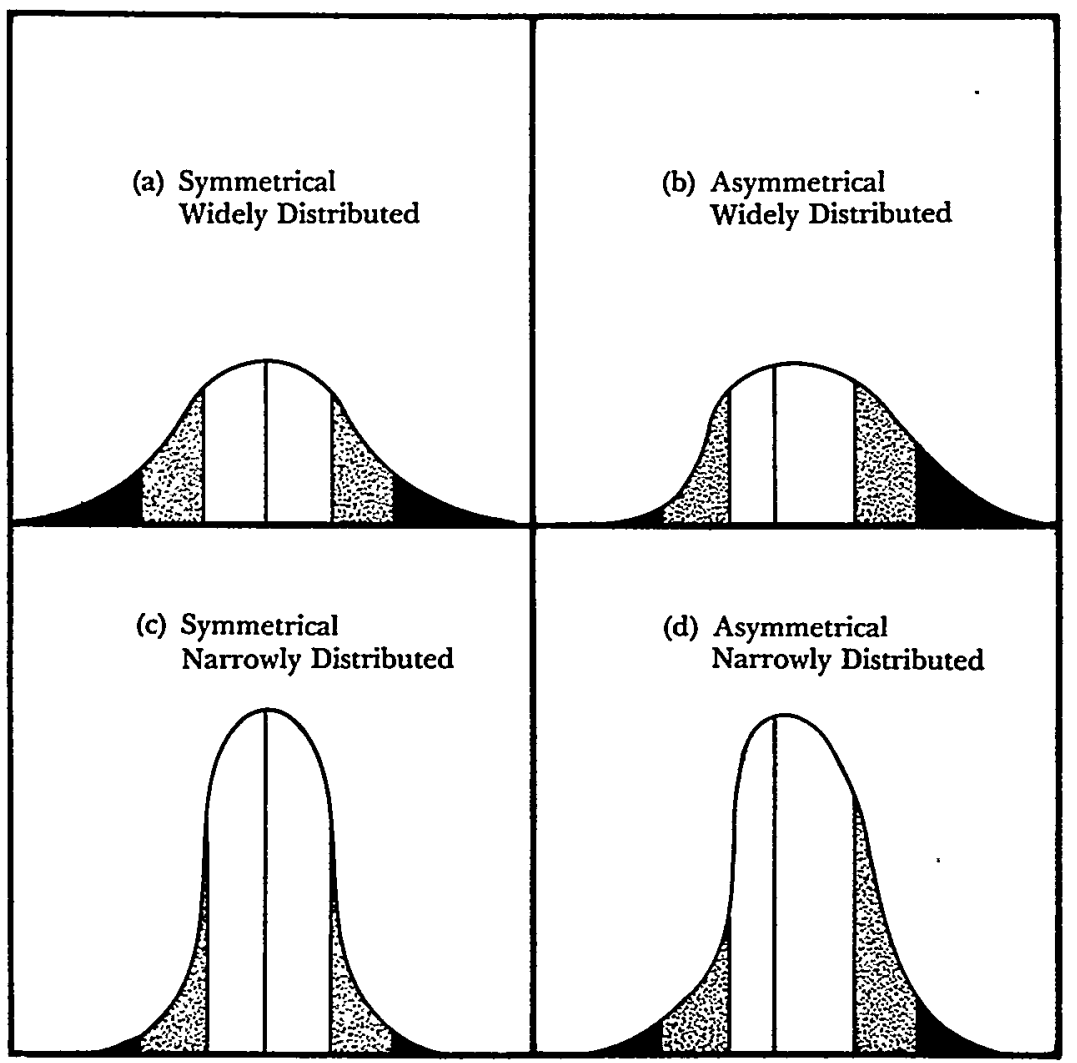

Extremely Prejudiced

Ex Prejudiced

$\square$ Mildly Prejudiced

Graph 4 illustrates that if the voir dire process is designed to achieve a jury of low and evenly distributed prejudice, then the distribution of prejudice within the venire will determine the form and extent of juror removal. If prejudice is widely and symmetrically distributed as in Graph 4(a), a relatively large number of prospective jurors will have to be removed, but the same number should be excused from both sides of the spectrum. A skewed distribution like that represented in Graph 4(b) will necessitate the removal of ap- 
proximately the same number of potential jurors, but more should be removed from one side of the spectrum than from the other. The distributions depicted in Graphs 4(c) and 4(d) will require fewer removals to obtain the same range of bias, because a greater proportion of the venire is closer to the no-bias point. The asymmetrical distribution in Graph 4(d), however, necessitates that the pro-prosecutorial bias be compensated for by removing more potential jurors who are prejudiced in that direction.

The appropriate result can be achieved in each case, provided sufficient challenges are available and are properly allocated, and provided sufficient information is available to identify the prejudiced jurors in the venire. ${ }^{60}$ The number and allocation of peremptory challenges available in both federal and state criminal trials vary according to the severity of the offense. Many jurisdictions give an equal number to both parties; some allow a larger number to the defense. ${ }^{61}$ The models presented in Graph 4 make it clear that the adequacy of such allocation depends upon the distribution of prejudice in the particular case. But even if the statutory allocation of peremptory challenges does not correspond precisely with the distribution of prejudice in the venire, an additional safeguard remains. The judge can use challenges for cause, which are not limited in number, ${ }^{62}$ to compensate for the inability of one side to correct an imbalance in prejudice favoring the opposing side. In order for challenges for cause to operate in this manner and in order for attorneys to identify less-prejudiced jurors who can be eliminated by peremptory challenges, sufficient information on the prejudice of jurors within the venire must be obtained.

Our experiment suggests that, on the whole, the voir dire as conducted in these trials did not provide sufficient information for attorneys to identify prejudiced jurors. ${ }^{63}$ The average performance score of the prosecution was near the zero point $(-0.5)$, indicating an inability to distinguish potential bias; ${ }^{64}$ defense counsel performed only slightly better $(+17.0)$. Perhaps most significant is the

60. This analysis, of course, is conditioned upon positive attorney performance in the exercise of their allotted peremptory challenges. If the attorneys perform neutrally or worse, the number and pattern of allocation of challenges will have no effect on producing the desired result.

61. See note 8 supra.

62. See note 6 supra.

63. See text accompanying notes $42-49$ supra.

64. We assume that some initial bias existed in the population of potential jurors in our study. 
inconsistent performance of attorneys. Occasionally, one side performed well in a case in which the other side performed poorly, thereby frustrating the law's expectation that the adversary allocation of challenges will benefit both sides equally. ${ }^{65}$

One way of averting the undesirable effects of disparate performance would be to increase the amount of information on which lawyers base their decisions. The more they learn in open court about the prejudice of potential jurors, the less opportunity there is for luck or private knowledge to determine which side benefits from the peremptory challenge process. The current trend is in the opposite direction and has tended to reduce the voir dire's informative power. To an even greater extent than before, judges have reduced the voir dire questioning by counsel and have transferred primary responsibility to themselves, questioning jurors in blocks and restricting the scope of the questions asked. ${ }^{66}$

There is, however, an interesting exception to this trend. In notorious cases with extensive pretrial publicity, the courts have tended to abandon all restrictive rules and have gone to the other extreme. In these cases, the courts apparently have considered it essential that as much as possible become known about each individual juror. They have allowed great latitude in the questioning of jurors, even to the extent of occasionally questioning each potential juror in chambers to assure the most frank and complete response. ${ }^{67}$

One rationale for distinguishing notorious cases from other cases in terms of the kind and extent of the questioning permitted of individual jurors is based on the assumption that the range of prejudice in the venire will exceed that in ordinary cases. Thus, the

65. The performance index used in our study is cruder than that required for the task outlined by the model depicted in Graphs 3 and 4 . The index gives counsel a positive score for every challenge of a juror on the correct side (that is, for every juror hostile to its side of the spectrum); it gives a negative score for challenges of jurors who would have voted for that side. The index does not distinguish the degree of prejudice (that is, the distance from the nobias point).

66. The move toward restricting the scope of the voir dire suggests that our juror selection process is becoming more closely akin to the English example, in which challenge for cause is limited to "specific" bias-blood relationship or similarly direct association with the parties-and peremptory challenges hardly ever are exercised. As a rule, jurors are not questioned at all, and the court impanels the first prospective jurors who come into the box. See note 10 supra and accompanying text.

It is difficult to see why the English system should serve as a model for our system. The English jury, unlike the American jury, never confronts the problem of widespread pretrial publicity because English law does not permit it. Moreover, we do not know how well the English model serves the ends of justice.

67. See, e.g., Zeisel \& Diamond, supra note 49 , at 153. 
ordinary trial takes on the venire constellations depicted in Graph 4(c), and the extraordinary trial is identified with that of Graph 4(b), in which prejudice is great and asymmetrically distributed. This rationale poses two difficulties.

First, the distinction between the ordinary and the extraordinary trial is often difficult to establish. The two lie on a continuum, and there is no demarcation point at which it becomes clear that different rules should apply. Moreover, the decision as to which trial deserves the mini-voir dire and which the full treatment is left entirely to the trial court's discretion; there are no guidelines for the judge to follow.

Yet another possible justification for reducing the extent of voir dire exists: the desire to obtain a jury that represents as closely as possible the community from which it is drawn. Recent years have seen major reforms designed to achieve this goal, efforts spearheaded by the Federal Jury Selection Act of $1968 .{ }^{68}$ A liberal policy of allowing challenges is likely to impair community representativeness. ${ }^{69}$ As one critic has observed, first we labor hard to make the juries representative of the communities from which they are drawn, and at the very last moment we allow that representativeness to be destroyed by peremptory challenges. ${ }^{70}$

This rationale for reducing the voir dire also is flawed. First, efforts to make the jury venires representative of their communities have been far from successful..$^{71}$ Second, a representative jury nevertheless may be representative of a prejudiced community. To be sure, a change of venue might bring relief, but that is a measure the law grants only in extreme circumstances. ${ }^{72}$

Because we argue for more information on juror prejudice, we should take a closer look at the nature of the "prejudice" we so glibly

68. 28 U.S.C. $\$ 1861$ (1970).

69. Cf. Note, Limiting the Peremptory Challenge: Representation of Groups on Petit Juries, 86 YALE L.J. 1715 (1977) (attorneys should be prevented from challenging jurors merely because they are members of certain groups within society).

70. Address by Swedish Judge Mars Molin at the 1974 Cropwood Conference on Jury Trials, held in Cambridge, England, under the auspices of the Cambridge Institute of Criminology.

71. See generally J. VAN DyKE, supra note 8. Note also that the drawing from the jury wheel may be manipulated to yield a purposefully biased jury. See Zeisel, Dr. Spock and the Case of the Vanishing Women Jurors, 37 U. CHI. L. REV. 1 (1969).

72. See aba Project on Minimum Standards for Criminal Justice, Standards ReLATING TO FAIR TRIAL \& FREE PRESS 121 (Approved Draft 1968) (not only is there a general reluctance on the part of courts to grant a change of venue, but several states have adopted statutes imposing substantial restrictions on the availability of this remedy). 
have located, graded, graphed, and altogether taken for granted. At its extreme, prejudice is easily identified as a predisposition that should not, but is likely to, affect a juror's vote. ${ }^{73}$ A close relative of the defendant or the victim safely may be assumed to be prejudiced, as may the drug-using juror in a drug case, or the racist in the trial of a black man. As we move away from these extremes, the identification of undesired prejudice becomes more complicated. If we are intent upon finding the completely impartial juror, we surely shall never find one. All jurors' experiences have shaped their values and attitudes, and these, in turn, are likely to shape jurors' perceptions of the trial evidence and hence their votes. In this sense, "prejudice" is not only ineradicable but often indistinguishable from the very values and attitudes of the community that we expect the jurors to bring to the trial. ${ }^{74}$

The law recognizes that jurors cannot perceive and evaluate the evidence before them without being affected by their attitudes and beliefs, and thus it insists that the differing values held by the jurors be adequately mixed. This insistence that the values of the jury be reflective of the distribution of values that exist in the community provides the law with an objective standard against which the "fairness" of the jury can be measured: A representative jury, then, is the first approximation to the ideal jury.

As its second approximation, the law, through the voir dire, tries to improve the selection process by removing the strongly biased jurors and by preventing whatever prejudice remains from being one-sided. This second approximation is more difficult to achieve. Potential jurors may hide their prejudices from the examiner, either consciously or unconsciously. In the end, it is difficult to define and describe the borderline between prejudice and value differences with any precision. Perhaps that is why the law in its wisdom does not require reasons for the peremptory challenge.

73. Psychological research has demonstrated that such prejudices can even distort perceptual abilities. See Note, Did Your Eyes Deceive You? Expert Psychological Testimony on the Unreliability of Ejewitness Identification, 29 STAN. L. REV. 969, 981 (1977).

74. "All people have biases and opinions that will inevitably influence their decisions and perceptions, including those on jury duty. The Supreme Court has recognized this in cases in which it finds that jury selection procedures must assure a 'fair possibility for obtaining a representative cross section of the community.' The reason for a cross section, stated explicitly in the opinions, is that it assures that a range of biases and experiences will bear on the facts of the case." Babcock, supra note 6, at 551 (footnote omitted). 
HeinOnline -- 30 Stan. L. Rev. 532 1977-1978 